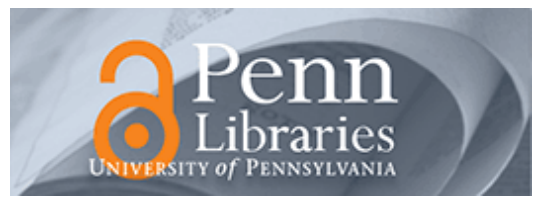

University of Pennsylvania

ScholarlyCommons

Accounting Papers

Wharton Faculty Research

$5-2016$

\title{
Abnormal Accruals in Newly Public Companies: Opportunistic Misreporting or Economic Activity?
}

Christopher S. Armstrong

Follow this and additional works at: https://repository.upenn.edu/accounting_papers

Part of the Accounting Commons, and the Business Administration, Management, and Operations Commons

Recommended Citation

Armstrong, C. S. (2016). Abnormal Accruals in Newly Public Companies: Opportunistic Misreporting or Economic Activity?. Management Science, 62 (5), 1316-1338. http://dx.doi.org/10.1287/mnsc.2015.2179

This paper is posted at ScholarlyCommons. https://repository.upenn.edu/accounting_papers/13

For more information, please contact repository@pobox.upenn.edu. 


\title{
Abnormal Accruals in Newly Public Companies: Opportunistic Misreporting or Economic Activity?
}

\author{
Abstract \\ Newly public companies tend to exhibit abnormally high accruals in the year of their initial public offering \\ (IPO). Although the prevailing view in the literature is that these accruals are caused by opportunistic \\ misreporting, we show that these accruals do not appear to benefit managers and instead result from the \\ normal economic activity of newly public companies. In particular, and in contrast to the notion that \\ managers benefit from inflating accruals through an inflated issue price, inflated post-IPO equity values, \\ and increased insider trading profits, we find no evidence of a relation between abnormal accruals and \\ these outcomes. Instead, consistent with these accruals resulting from normal economic activity, we find \\ that these accruals are attributable to the investment of IPO proceeds in working capital and that \\ controlling for the amount of IPO proceeds invested in working capital produces a more powerful accrual- \\ based measure of misreporting.

\section{Keywords} \\ misreporting, earnings management, financial reporting quality, accruals, incentives, insider trading, initial \\ public offering, new issues puzzle, investment \\ Disciplines \\ Accounting | Business Administration, Management, and Operations
}




\title{
Determinants and trading performance of equity deferrals by corporate outside directors ${ }^{\mathrm{a}}$
}

\author{
Francesca Franco \\ London Business School \\ ffranco@london.edu \\ Christopher D. Ittner \\ University of Pennsylvania - The Wharton School \\ ittner@wharton.upenn.edu \\ Oktay Urcan ${ }^{b}$ \\ University of Illinois at Urbana-Champaign \\ ourcan@illinois.edu
}

\begin{abstract}
This study investigates the determinants and trading performance of outside directors' equity deferrals, which represent the choice to convert part or all of their annual cash compensation into deferred company stock. Using a large sample of S\&P1500 firms that allowed directors to defer their cash fees into equity between 1999 and 2009, we find significant associations between equity deferral choices and specific features of the director compensation plans, proxies for directors' outside wealth diversification, and future firm stock market performance. Trading performance analyses indicate that outside directors earn substantial abnormal returns from their deferrals, with a significant proportion of the deferral transactions occurring during blackout periods. These results are consistent with companies structuring director equity deferral plans to circumvent SEC Rule 10b-5’s trading restrictions.
\end{abstract}

Key words: outside directors; deferred compensation; insider trading; SEC Rule 10b-5 plans.

\footnotetext{
${ }^{a}$ We are grateful to Mary Barth (the department editor), an anonymous associate editor, and three anonymous referees for very constructive comments. We also appreciate helpful suggestions from Jennifer Blouin, Philip Bond, Peter Christensen, Alex Edmans, Dave Larcker, Scott Richardson, Irem Tuna, David Yermack and workshop participants at the University of Alberta, London Business School, London School of Economics, University of Pennsylvania, and Tilburg University.

${ }^{\mathrm{b}}$ Corresponding author
} 


\section{Introduction}

A long line of research in accounting and finance has examined the design of executive and director compensation plans, with a particular emphasis on the choice between cash and equity incentives (see Murphy, 1999; Core et al., 2003; Edmans and Gabaix, 2009 for reviews). The past decade has seen an increasing number of firms offer their corporate board members the option to convert some or all of their annual cash compensation into deferred company stock, to be delivered upon termination of service (see Frederic Cook \& Co. Inc., 2012-2014). These “equity deferral options” are interesting for two reasons. First, when exercised, executives and directors give up a sure amount of cash today for equity with uncertain future value, while substantially increasing the proportion of their annual pay that is tied to future firm performance. Second, the equity deferrals can act as a form of insider trading, with the deferral plans structured to circumvent SEC Rule 10b-5’s trading restrictions.

We focus on equity deferral choices by outside directors for three reasons. First, proxy statement descriptions of the director deferral plans allow us to determine whether the directors made the choice to defer current cash compensation into future stock. Such choices cannot be measured unequivocally for corporate executives since the deferral options offered to executives usually allow them to defer any part of their annual compensation (i.e., cash and/or equity) into equity, with the deferral of current equity usually made for tax reasons. Second, equity deferral choices by outside directors typically are less affected by the liquidity and diversification constraints of corporate executives, since most of their earned income and cumulated wealth comes from outside the firm. Third, equity deferrals represent an un-investigated setting to study outside directors' decisions to invest in the firm's stock, thereby contributing to the scarce empirical evidence on insider trading by outside board members.

We examine the determinants and trading performance of director equity deferrals using a large hand-collected sample of S\&P1500 firms that allowed outside directors to defer their cash compensation into equity between 1999 and 2009. Sample distributions across years and S\&P indices indicate that the proportion of firms offering equity deferral options to directors significantly increased over the years and as a function of firm size. Among S\&P500 firms, an average of $58 \%$ of the firms offered these options to directors, with an increase from $46 \%$ in 1999 to $63 \%$ in 2009. We first investigate the board and firm characteristics associated with the firm's choice to offer equity deferral options to directors. Results from these analyses indicate that the options are used by larger firms as a substitute for standard director stock option and share grants and as a means to allow directors to increase their existing ownership in the firm. Among other firm characteristics, the likelihood that a firm offers equity deferral options to 
directors also varies with the provision of similar options to executives, the firm's cash constraint status, and past performance.

We next investigate the factors affecting directors' equity deferral decisions. We collect equity deferral transaction data from Thompson Insider trading filings and test the associations between the equity deferrals and three sets of variables: specific contractual features of the director compensation plan; the firm's future stock market performance; and a vector of director personal characteristics. We find that variables measuring each of these dimensions are significantly associated with sample directors' equity deferrals. Controlling for the amount of deferrable cash and existence of premiums, director equity deferral values increase with the predeferral director compensation paid through equity. This result suggests that the perceived under-diversification costs brought about by the deferrals are lower for directors already committed to compensation contracts with higher equity incentives. Consistent with information arguments, we find strong positive associations between the directors' equity deferrals and: i) the deferral elections made by corporate executives; and ii) the firm's future stock market performance. Directors’ personal characteristics are also significant predictors, with the deferred amounts decreasing with proxies for the directors' wealth currently tied to firm performance and increasing with proxies for the directors' outside wealth diversification.

Our results are robust to a variety of model specifications and hold over a sub-sample of directors serving on multiple boards. This sub-sample is particularly relevant for the purposes of our analyses because those unobservable director characteristics likely associated with the decision to defer (e.g., the director's outside wealth and/or risk aversion) are held constant across all boards the directors serve on. Moreover, since multiple-board directors often elect to defer in some firms but not in others, this sub-sample provides a powerful setting to examine the relative importance of insider information versus other factors such as contractual features and directorship characteristics in motivating directors to purchase equity through deferrals.

Our third set of analyses examines the trading performance of director equity deferrals. We assess the level of private information outside directors exploit through their deferrals by measuring the abnormal returns the directors earn from these transactions using various horizons and alternative abnormal returns measures. Across all measurement windows and estimation methods, deferring directors realize significant abnormal returns from their deferrals. Comparisons to the returns the non-deferring directors would have realized if they had exercised their equity deferral options at their firms suggest that the abnormal returns result from deferring directors conditioning their transactions based on some form of insider information. Consistent with these conjectures, results from cross-sectional analyses show that the returns vary significantly with various proxies for the directors' monitoring abilities and access to material 
private information at their firms. The abnormal returns deferring directors realize are higher in firms with low governance quality and boards with higher proportions of insiders, and lower in firms with higher analyst coverage and more frequent management forecasts. These results provide strong evidence that directors earn larger returns in settings where their ability to acquire and trade upon private information about the firm is higher.

Finally, we investigate whether equity deferrals provide a mechanism for directors to conduct stealth insider trading in periods when open market purchases of the firm's stock would violate U.S. Securities and Exchange Commission (SEC) Rule 10b-5. Rule 10b-5 is the antifraud provision promulgated in the Securities Exchange Act of 1934. The rule defines "stealth" insider trading as the act of buying or selling a security, in breach of a fiduciary duty or other relationship of trust, while in possession of "material non-public information" about the security. The SEC has expressed concerns that executives and directors can use Rule 10b5-1 plans to sidestep blackout period trading restrictions. Rule 10b5-1 plans allow insiders to make trades pursuant to a pre-set schedule that provides them with an affirmative defence against claims of insider trading. Trades under 10b5-1 plans are not subject to trading restrictions during blackout periods. Since companies can design director deferral plans to comply with 10b5-1 rules, directors can use the deferrals to effectively conduct stealth insider trading. ${ }^{1}$ Our blackout period trading results strongly support these concerns.

Our paper makes four primary contributions. By examining equity deferral options together with other director compensation and board characteristics, we extend the limited literature on the firm's provision of equity incentives to outside directors (e.g., Hermalin and Weisbach, 1991; Yermack, 2004; Ryan and Wiggins, 2004; Fich and Shivdasani, 2005; Linn and Park, 2005). Second, our analyses of the determinants of directors' equity deferrals allow us to contribute to related research on employees' decisions to invest in the firm's equity through savings plans or stock purchases (e.g., Benartzi, 2001; Lakonishok and Lee, 2001; Piotroski and Roulstone, 2005; Benartzi et al., 2007). In particular, director equity deferral choices provide evidence on the factors influencing directors' revealed preference for equity versus cash pay. Third, our results extend the limited evidence on the information content of outside directors' insider trades (Ravina and Sapienza, 2009; Cook and Wang, 2011). The availability of a sample that includes multiple directors who are covered by the same firm's compensation contract and share the same information environment, as well as directors who sit on multiple boards but vary their deferral choices by company, allows us to disentangle the relative importance of personal, contractual, and firm-specific information explanations on director trading activities.

\footnotetext{
${ }^{1}$ Sections 2 and 5.2 provide further details on the application of Rules 10b-5 and 10b5-1 in the context of nonqualified deferred compensation plans.
} 
Perhaps most importantly, our study provides further evidence on strategic insider trading under 10b5-1 plans (Jagolinzer, 2009), an issue of considerable SEC interest. Although Ravina and Sapienza (2009) find that outside board members earn abnormal returns from their purchases, they do not investigate how directors can conduct informed trades without violating SEC Rule 10b-5. Our trading results provide evidence that outside directors can use 10b5-1 compliant deferral plans to trade while circumventing Rule 10b-5's restrictions.

The remainder of the paper consists of six sections. Section 2 provides institutional details on the deferral options available to corporate outside directors. Section 3 presents our sample and tests for the firm's choice to offer equity deferral options to directors. Section 4 presents results from analyses investigating the factors affecting directors' equity deferrals. Section 5 investigates the trading performance and timing of the deferrals. Section 6 concludes.

\section{Institutional background}

Deferral options for outside directors are a common compensation element in U.S. boardrooms (see National Association of Corporate Directors, 2004; Conference Board, 2006). When exercised, the option to defer cash compensation into equity has two significant consequences for the directors. First, the directors face no current taxation on the cash that is deferred. To remain untaxed, however, the deferrals plus the investment returns must be unfunded. ${ }^{2}$ Second, the value of the shares received at the time of the deferral equals the amount of the deferred cash, but their ultimate value will depend upon stock price changes over the deferral period (typically the end of the director's mandate on the board). Conventional wisdom suggests that tax benefits drive the decision to defer, since pre-tax deferrals generate larger returns than an investment in the firm's stock made with after-tax dollars. However, the gains from pre-tax deferrals may not be sufficient to compensate the directors for the risks they assume by deferring into an instrument with uncertain ultimate value (see Den Uyl, 1998; Ronald and Topper, 1998). These arguments imply that the deferrals could benefit directors by providing a tax-advantaged alternative to open market purchases of the firm's shares.

Compensation and governance commentators argue that equity deferral options can also allow directors to achieve a variety of non-tax objectives. First, these options give directors the flexibility to adjust their compensation mix to their personal preferences and employment circumstances (see Baldwin and Wilson, 1998). Second, equity deferral plans have been promoted as an effective means to increase directors’ ownership in the firm (e.g., Mercer

\footnotetext{
2 Equity deferrals (as well as pensions and cash deferrals) are nonqualified compensation arrangements under IRC§409A tax rules. For directors to defer income tax on this compensation, these arrangements are almost always unfunded and unsecured, and therefore at risk of insolvency like other unsecured debt if the firm becomes financially distressed (see McNeil, 2009).
} 
Consulting, 2003; Conference Board, 2006), with some firms using these options to allow directors to meet stock ownership guidelines in a cost-effective and flexible manner. Third, survey evidence suggests that an increasing number of firms have introduced director deferral plans, which are similar in many respects to tax-advantaged savings plans that allow investments in the company stock, as replacements for contentious director retirement plans (MCG Consulting Group, 1999; Campbell et al., 2006). ${ }^{3}$

The Appendix to the paper provides examples of common proxy statement descriptions of the deferral plans firms offer to corporate outside directors. These disclosures range from approximately 100 to 800 words describing the deferral options available to directors. Most firms give directors full discretion over how much cash to defer in the year and whether to redefer amounts deferred in previous years. In case of re-deferrals, the transaction is recorded as if the director receives the cash equivalents from her prior deferrals and re-makes the choice to further defer these in stock units. The election to defer into the company's stock may be accompanied by an automatic grant of additional shares (i.e., "premiums”), usually expressed as a percentage of the deferred cash. Firms often provide directors with the alternative option to invest the deferred amounts into interest crediting cash accounts rather than in equity. Under such arrangements, the directors can defer the cash compensation into either the company's accounts and earn a fixed or variable rate based on some formula or index (e.g., such as prime rate or cost of capital), ${ }^{4}$ or into deferred stock units and gain from stock price improvements.

Firms currently are not required to disclose outside directors' deferred compensation amounts, whether made in interest crediting cash accounts or in equity, in their proxy statements. ${ }^{5}$ The only exception is when the deferrals generate phantom shares. In this case, the deferred stock units must be reported in a summary table of the "Director Compensation" subsection of the firm's proxy statements. For all other equity deferrals, the only publicly available information on these transactions can be retrieved from the Form-4 insider trading filings the SEC requires directors to submit upon the election to convert cash into deferred stock units.

Directors receive their first option to defer upon their election to the board. In subsequent years, directors usually are allowed to defer at the end of the year preceding the year in which

\footnotetext{
${ }^{3}$ We observe trends consistent with this evidence in our sample, with a significant increase in the proportion of firms with director ownership guidelines and a rapid disappearance of director retirement plans after 2004. While in 1999 only 8\% of sample firms had director ownership guidelines, by 2009 45\% of the firms had such guidelines. Similarly, the proportion of firms with director retirement plans decreased from 13\% in 1999 to $0.9 \%$ after 2004 .

${ }^{4}$ Of the firms in our sample that disclose the cash investments offered to directors, $22 \%$ offer an indexed yield based on prime rates, $16 \%$ a rate based on the average 6-month, 5-year, or 10-year treasury bond rates, and $8 \%$ a rate tied to long-term debt, such as the Moody's corporate bond rate or the applicable U.S. federal rate published by the IRS. The rest credit a variable rate based on various corporate investment or employee savings funds.

5 Although the SEC proxy rule reform of 2007 requires public firms to disclose detailed information about executive pension benefits and deferred compensation, the SEC still does not require firms to report this information for outside directors (see http://www.sec.gov/rules/final/2006/33-8732afr.pdf for more details).
} 
the cash will be earned, or based on a pre-set schedule, such as at the beginning of each quarter. Other firms do not disclose restrictions on the frequency and timing of the deferrals, with the directors being allowed to defer at any time in the year.

When based on a pre-set schedule, the equity deferral plans can be structured to meet the requirements of SEC Rule 10b5-1 (see, for example, the extract from First Community Bank's 2005 proxy statement in the Appendix). This rule provides an affirmative defence against claims of insider trading if the 10b5-1 plan's trading schedule was set at a time when the person was not aware of any material non-public information. Firms currently are not required to report to the SEC or disclose to shareholders their 10b5-1 plans' details. A number of additional loopholes in the rule, such as the ability of companies to enter into, amend, or cancel these plans on short notice, and/or of directors to cancel pre-scheduled transactions without penalties (since the SEC does not consider a "non-purchase” to be a violation of Rule 10b-5) has led the SEC to raise concerns that deferral plans set in accordance with Rule 10b5-1 help directors to circumvent insider trading restrictions (Good et al., 2013; Pulliam and Barry, 2013). ${ }^{6}$

\section{Firms offering equity deferral options to directors}

\subsection{Sample construction}

We begin constructing our sample from the population of firms at the intersection of ExecuComp and RiskMetrics over the years 1999 to 2009. We require firms' coverage on both datasets to collect information on outside directors' annual compensation and selected directorlevel characteristics we use in our analyses. For all firms in the ExecuComp-RiskMetrics intersection (i.e., 14,017 firm-years), we conduct a keyword search on LivEdgar to identify those firms allowing directors to defer annual cash compensation into deferred stock units in the year. Our keyword search requires the words "defer" and/or "deferred" to appear in the “Director Compensation” sub-section of the firms' definitive annual proxy statements. We read all proxy statements generated through this search (approximately 5,500) to identify firms allowing directors to voluntarily defer their annual cash retainers and meeting fees into equity in the year and to eliminate those firms granting automatic deferred stock units to directors or allowing directors to defer both cash and equity compensation (fewer than $3 \%$ of the firms). This process yields an initial sample of 5,389 firm-years offering equity deferral options to outside directors between 1999 and 2009. For this sample, we hand-collect information on

\footnotetext{
${ }^{6}$ A 2013 survey by TheCorporateCounsel.net finds that 79\% of responding firms do not make public disclosures of insiders' 10b5-1 trading plans, 91\% allow 10b5-1 share trades during blackout periods, 77\% require a one month or shorter waiting period between the execution of a 10b5-1 plan and the time of the first equity transaction, and $82 \%$ allow participants to voluntarily terminate a 10b5-1 plan without consequences for the insiders (see http://www.thecorporatecounsel.net/blog/2013/06/survey-results-10b5-1-plan-practices-1.html ).
} 
specific features of the director deferral plans, as well as other director compensation characteristics we control for in our analyses.

Table 1 provides details on the number and proportion of firms offering equity deferral options to outside directors between 1999 and 2009. Table 1 - Panel A reports sample compositions by year and S\&P size indexes. Sample distributions indicate that the proportion of firms offering equity deferral options has significantly increased over time and as a function of firm size. Across the entire sample period, about 38\% of the firm-years offer these options to directors, with the proportion of firms increasing from 31\% in 1999 to $43 \%$ in 2009. The frequency of firms with equity deferral options is significantly higher among S\&P500 firms, where about $58 \%$ of the firms offer these options across all years, with a steep increase from 46\% in 1999 to 63\% in 2009. We observe similar, albeit less steep, trends among MidCap firms. SmallCap and No-Index firms report a significantly lower proportion of firms offering equity deferral options to directors (i.e., 27\% across all years).

Table 1 - Panel B reports sample composition by Fama-French (1997) 12-industry classifications and S\&P500 Index. We observe significant sample variation across industries, with the chemicals (74\%), utilities (63\%), manufacturing (50\%), and finance (45\%) sectors reporting the highest proportion of firms offering equity deferral options to directors. ${ }^{7}$ Industry concentration is more pronounced among S\&P500 firms, with the proportion of firms ranging from $67 \%$ in the finance sector to $83 \%$ in the chemicals sector.

\subsection{The firm's choice to offer equity deferral options}

In this section, we investigate the board and firm characteristics associated with the firm's likelihood of offering equity deferral options to outside directors. We first examine whether these options are used by firms as a substitute for standard director stock option and share grants and/or as a means to allow directors to increase their existing ownership in the firm (e.g., Mercer Human Resource Consulting, 2003; Conference Board, 2006). ${ }^{8}$ If equity deferral options are used to accomplish these objectives, we expect firms with lower proportions of director equity pay and lower outside directors’ existing ownerships in the firm to be more likely to offer these options to directors. ${ }^{9}$ Similarly, if equity deferrals are used by firms as tax-

\footnotetext{
${ }^{7}$ Sample distribution across industries is relatively stable over our sample period.

${ }^{8}$ Firms' explanations for offering equity deferral options to outside directors often support these incentive-based motivations. For example, Apogee Enterprises’ Compensation Committee Report of 2003 states: “This plan was adopted by the Board to encourage the non-employee directors to continue to make contributions to the growth and profits of Apogee and to increase their ownership of our common stock, thereby aligning their interests in the longterm success of Apogee with that of our other shareholders (Proxy Statement filed on May 13, 2003)”.

${ }^{9}$ Ideally, we would also control for the existence of minimum ownership guidelines for directors, but doing so would require hand-collecting this information from the proxy filings of all firms in the whole 1999-2009 ExecuComp-RiskMetrics intersection (not just for the firms offering equity deferral options).
} 
advantaged alternatives to director open market purchases of the firm’s shares, we expect firms located in states with higher marginal income personal tax rates to be more likely to offer these options to directors. \% Dir Equity Comp is the average proportion of outside directors' annual equity pay for the year, measured as the value of the share and option grants made to the directors in the year divided by directors' total pay (i.e., sum of cash retainers, meeting fees and equity grants). Prior to 2006, ExecuComp provided the number but not the value of the stock options and shares granted to outside directors. Consequently, for the 1999-2005 sub-period, we estimate the value of the director equity grants based on the average price and average BlackScholes value of the shares and stock options granted to the firm's executives during the year. \% Dir Sharesheld measures the proportion of the firm's shares outstanding held by the firm's outside directors at the end of the prior year. \% Income Tax Rate is the maximum personal income tax rate of the state in which the firm is headquartered. ${ }^{10}$

We also expect equity deferral options to be more likely offered to directors when the proportion of outside directors on the board is higher and when the firm offers similar "cash-toequity" deferrals to corporate executives. \% Outside Directors measures the proportion of firm board members with the "dirtype" field in RiskMetrics equal to "I” (i.e., "Independent Director”) and "L” (i.e.., "Linked Director"). ${ }^{11}$ Option To Executives is an indicator variable capturing whether the plan offers similar options to executives. Moreover, since equity deferral options have features that are common to equity grant decisions, we follow prior literature on executive equity grants (e.g., Demsetz and Lehn, 1985; Smith and Watts, 1992; Yermack, 1995; Core and Guay, 1999) and investigate the effects of firm characteristics that have been shown to be related to the firm's decision to grant equity to executives. $\log _{V} E_{t-1}$ is the logarithm of the firm's market value of equity at the end of year $t-1 . M B_{t-1}$ is the firm's market to book value of equity at the end of year t-1. Following prior literature, we expect larger firms and firms with higher investment opportunities to be more likely to offer equity deferral options to directors. In addition, since the option to defer into equity usually comes in conjunction with alternative deferral options (discussed in Section 2) and neither requires cash payouts from the firm, we expect firms with cash constraints to be more likely to offer these options to directors. We follow Core and Guay (1999) and proxy for a firm's cash constraint status with the past threeyear average of [(common and preferred dividends + cash flow used in investing activities -

\footnotetext{
10 According to U.S. state personal income tax codes, director fees are taxed based on the tax rate of the state in which the board meetings are held, independent of whether the director resides in the state. If the director does not reside in that state, the director must file a non-resident personal tax return and pay taxes on the earned fees. Since most U.S. states apply source tax jurisdiction and provide a credit against the resident income tax for any nonresident tax paid in another state on the same income items, this is equivalent to the director been taxed on her fees based on the income tax rate of the state in which the firm is headquartered.

${ }^{11}$ Excluded from the count are board members with RiskMetrics “dirtype” field equal to “E” (i.e., “Employee”).
} 
cash flow from operations)/total assets] measured at the end of year t-1. Finally, we control for the potential association between equity deferral options and firm performance by including the firm's past stock returns and past returns' volatility. Stock Returnst-2,t-1 measures the firm's market-adjusted annualized stock returns over the prior two years. Annual returns are constructed from compounded monthly returns. SD(Stock Returnst-2,t-1) measures the standard deviation of the firm's monthly stock returns over the prior two years.

Table 2 presents analyses of the firm's choice to offer equity deferral options to outside directors. Table 2 - Panel A presents descriptive statistics for the hypothesized set of determinants for the sub-sample of ExecuComp-RiskMetrics firms with available data on the selected variables (i.e., 11,958 firm-years, consisting of 4,735 offering and 7,223 not offering equity deferral options to directors, respectively). ${ }^{12}$ The average firm in the sample has approximately $81 \%$ of board members who are outsiders. Outside directors receive about 52\% of their board compensation in the form of equity, and hold about 16 basis points of the firm's shares outstanding at the end of the prior year. The average state's income tax rate is about $6 \%$. Only 7\% of the firms offer similar "cash-to-equity" deferral options to corporate executives.

Table 2 - Panel B presents univariate comparisons and results from a logit model examining the firm's choice to offer equity deferral options to outside directors in the year. The model includes both industry and year fixed-effects and clusters z-statistics at the firm level. Both univariate analyses and logit results indicate that the likelihood of equity deferral options significantly increases with the firm's board proportion of outside directors, and decreases with both the proportion of outside directors' equity pay and existing ownership in the firm. In terms of marginal effects from the logit estimates, moving from the bottom to the top quartile in the proportion of outside board members increases the likelihood of equity deferral options by about $17 \%$. Moving from the bottom to the top quartile in the proportion of director equity pay and proportion of shares held by the directors decreases the likelihood of equity deferral options by about $3 \%$ and $5 \%$, respectively. These results are consistent with the options being used as substitutes for standard director stock option and share grants, and as a means to allow directors to increase their ownerships in the firm. We find no evidence that the firm's state income tax rate affects the likelihood of deferral options being offered to directors.

Among other firm-level characteristics, the likelihood that a firm offers equity deferral options also increases with the firm's provision of similar options to executives, firm size, and cash constraint status, and decreases with the firm's past stock performance and volatility in past

\footnotetext{
12 The sample of 4,735 firm-years with equity deferral options is smaller than the original sample of 5,389 firmyears presented in Table 1, because of data unavailability on the selected set of determinants for the firm's choice to offer equity deferral options to outside directors used in Table 2.
} 
returns. Firm growth opportunities do not seem to affect the firm's choice to offer equity deferral options to directors. In subsequent robustness tests, we include the Inverse-Mills ratio from the logit estimation reported in Table 2 - Panel B as an additional control in models examining outside directors’ equity deferral choices.

\section{Determinants of director equity deferrals}

\subsection{Director equity deferral transactions}

In this section, we report summary statistics on the equity deferrals registered by sample firms' outside directors. We build our sample of equity deferral transactions as follows. For the subset of 5,389 ExecuComp-RiskMetrics firm-years with equity deferral options between 1999 and 2009, we download all insider trading transactions from Thompson Insider security and derivative filings (Tables 1 and 2, respectively). The dataset provides detailed information on firm insiders' trading activities as reported on Forms 3, 4, and 5 to the SEC, including the name and identification number of each insider, three different "role-code" fields for the various positions held at the firm (e.g., director, board committee member, officer, affiliated, beneficial owner, and other position), transaction dates, number of shares bought or sold, and the price of the transactions. ${ }^{13}$ We identify equity deferrals by requiring the "sectype" and "derivative" type fields in Thompson Insider's tables to equal "DEFR" (i.e., Deferred Compensation) or "PHTNM" (i.e., Phantom Stock). The "PHNTM" field is used only for those cases in which the firm explicitly states in the annual proxy statement that the phantom stocks acquired by the director originated from deferrals in accordance with the firm's director deferred compensation plan. To avoid missing transactions because of misclassifications in the insider's role-type on Thompson Insider, we first extract the insider's last, middle, and first names, and then merge these to the "last name," "middle name," and "first name” fields in RiskMetrics. This process allows us to match about $97 \%$ of the insiders with Thompson Insider's “role-codes1-3” fields equal to "D" (i.e., "Directors") to directors with the "dirtype" field in RiskMetrics equal to "I" (i.e., "Independent Director”) or “L” (i.e., "Linked Director”). ${ }^{14}$ We then require the identified deferral transactions to have available information on the number of underlying shares and price, and the directors to have non-missing annual compensation data and selected director characteristics in ExecuComp and RiskMetrics. Our final sample of director equity deferrals

\footnotetext{
13 Thomson Insider records three separate date fields for each insider trade: 1) the day on which the transaction occurred (i.e., "trandate" field); 2) the day on which the insider's Form 4 was received in a pdf file by the SEC (i.e., "secdate" field); and the day on which the file was entered in the SEC's database (i.e., "createdate” field). The field we use in our analyses is the "trandate" field in which the deferral option was exercised (and the stock unit recorded), since the returns the deferrals generate start from this date.

${ }^{14}$ Eliminated from our sample are board members with "officers types" affiliation codes in any of the three "rolecodes” fields on Thompson Insider (i.e., "RoleCodes1-3” equal to 'AV', 'CEO', 'CFO', 'CI', 'CO', 'CT', 'EVP', 'H', 'O', 'OB', 'OD', 'OP', 'OE', 'OS', 'OT', 'OX', 'P', 'S', 'SVP', 'VP’).
} 
consists of 53,015 transactions filed by 9,935 outside directors in 2,078 out of the 5,389 firmyears allowing equity deferrals. ${ }^{15}$

Figure 1 reports the average number of transactions by time of the year. The figure shows that directors trade in each month of the year. The average (median) days between the earliest and latest deferral transaction dates within each firm-year in the sample is 295 (321), suggesting that sample directors were able to defer any time between January and December at their firms, but cluster their transactions around the beginning of each quarter and the end of the year. These patterns are consistent with those proxy statement deferral plan descriptions allowing directors to defer based on pre-scheduled quarterly instalments and/or by the end of the year preceding the year in which the cash will be earned. Analyses in Section 5 investigate whether the timing of the deferrals reflect directors' exploitation of insider information and the use of 10b5-1 compliant deferral plans as a mechanism to conduct stealth insider trading.

Table 3 reports descriptive statistics on the director equity deferrals in our sample. Table 3 - Panel A presents statistics on the number and proportion of outside directors filing at least one deferral transaction in the year. Across all years, an average of six directors elected to defer cash compensation into deferred stock units. This statistic corresponds to about $60 \%$ of the firm's outside directors and indicates that, in firms with at least one deferring director, a relatively large number of directors elects to do so. Table 3 - Panel B presents statistics on the number of transactions, the amount deferred per transaction, and the total amount deferred in the year, expressed both in absolute value and as a proportion of the total cash compensation (i.e., the sum of annual retainer and meeting fees) earned by the director in the year. The dollar value of the deferrals equals the value of the deferred stock units on the day the transactions were filed, as reported in the "trandate" field in Thompson Insider. Sample directors registered about six transactions per year and elected to defer an average of about $\$ 36,000$ (median $=\$ 15,000$ ) per transaction, equivalent to an annual total deferral value of about $\$ 135,700$ (median $=$ $\$ 75,200)$. Since all firms in our sample allow directors to defer a fraction up to $100 \%$ of their annual cash retainers and fees, and to re-defer previously deferred compensation, the total amount deferred in the year may be higher than the total cash compensation earned for that year because of re-deferrals. ${ }^{16}$ In these cases, we assume that the director deferred $100 \%$ of her cash

\footnotetext{
15 The remaining 3,311 firm-years are firms where no director deferred cash into equity in the year.

16 As mentioned in Section 2, re-deferrals are recorded as if the director receives the cash equivalents from her prior deferrals and re-makes the choice to defer these in stock units. For example, if a director deferred a cash retainer of $\$ 50$ (equivalent to 5 stock units based on a price of $\$ 10$ per share) in 2008, and in 2009 elects to re-defer the cash equivalents generated from the deferral made in 2008 (now worth e.g., \$75, at a current share price of \$15) and makes a new deferral of $\$ 30$ (equivalent to 2 more stock units at the current share price of $\$ 15$ ), the transaction will be recorded for a total of 7 stock units (and a transaction value of \$105). Directors are not required to report the split between re-deferred and newly deferred stock units in their Forms 4.
} 
compensation for that year. Based on this assumption, deferring directors elected to defer an average of about $82 \%$ of their annual cash compensation per year.

\subsection{Contractual features}

We expect several features of the director compensation contracts to affect directors' equity deferral decisions. First, we predict director equity deferrals to depend upon the predeferral director compensation mix. If compensation mix reflects risk preferences (i.e., propensity towards risk), deferral values are expected to be higher for directors who have accepted pre-deferral compensation contracts that already link a larger proportion of their annual pay to firm stock market performance. \% Equity Comp is the proportion of the director's total annual compensation paid in equity (i.e., full value share and stock option grants). We cannot, however, exclude the alternative possibility that directors who already receive a larger proportion of their pay in the form of equity may defer lower amounts because of the underdiversification effects brought about by the deferral (e.g., Ofek and Yermack, 2000; Ke et al., 2003; Huddart and Ke, 2007). To control for the possibility that directors with higher equity incentives also receive higher cash compensation levels that are deferrable in the year, we add a control for the director's annual cash compensation (i.e., sum of annual retainer and meeting fees). Since all firms in our sample allow directors to defer a fraction up to $100 \%$ of their cash compensation, Cash Deferrable measures the maximum amount deferrable for the year. We also expect equity deferrals to vary with the presence of other director compensation arrangements. As discussed earlier, firms can offer equity deferral options as a cost-effective means for directors to reach required minimum ownership levels before the end of their mandates. To control for this possibility, we hand-collect an additional variable from sample firms' proxy statements (i.e., Ownership guidelines) indicating whether the firm requires corporate directors to reach a minimum ownership level by the end of their mandates. If equity deferrals are used by directors to meet required ownership levels, we expect larger deferral values in the presence of minimum ownership guidelines.

Finally, we expect director equity deferrals to vary with specific features of the director deferral plan. As described above, the plan can offer the option to defer into alternative investment cash accounts and/or the grant of additional stock units if the directors choose to defer into the firm's stock. Alternative indicates whether the plan offers the option to defer into alternative investments. All else equal, we predict equity deferrals to decrease in the presence of alternative (potentially less risky) investments. To control for the possibility that the equity deferrals are driven by premiums that make the choice to defer in stock units relatively 
“cheaper," we control for the size of the premiums directors receive. Premium Amount measures the proportion of deferred cash granted as a premium.

Table 4 - Panel A reports descriptive statistics on the compensation arrangements for sample directors. Across all years, the average director earns deferrable cash compensation of about $\$ 54,500$ and receives about $49 \%$ of the total annual compensation in the form of full value shares and/or stock option grants. About $22 \%$ of sample directors are subject to minimum ownership guidelines, and approximately $66 \%$ of directors receive the option to invest the deferred cash in alternative investment accounts. Premiums are rarely offered as incentives for directors to defer into equity (only $8 \%$ across years). When offered, premiums range from $5 \%$ to $50 \%$, with an average of $21 \%$ of the deferred cash.

\subsection{Firm prospects}

Studies on employee stock purchases indicate that insiders are more likely to purchase shares in periods preceding stock market improvements (e.g., Lakonishok and Lee, 2001; Piotroski and Roulstone, 2005; Kallunki et al., 2009; Ravina and Sapienza, 2009). Similarly, since the ultimate value of the deferrals will depend upon the firm's future market performance, we predict director equity deferrals to depend upon directors' expectations regarding the firm's future prospects. We measure directors' expectations using two different assumptions regarding their forecasting abilities. We first assume that directors cannot predict beyond one year. Accordingly, we measure the firm's stock market performance over the year after the director receives the option to defer cash into equity. Stock Returns $t_{t+1}$ measures the firm's marketadjusted stock returns over the next year. We then relax this assumption and examine whether directors formulate their deferral elections based on the expectations they may have for the period up to the year in which they will cash in their deferred equity. Stock Returns horizon measures the firm's market-adjusted annualized stock returns up to the year in which the director will end her current directorship in the firm (i.e., the "yearend” field in RiskMetrics). All else equal, we expect both future firm performance measures to be positively associated with the directors' deferred amounts. We also consider the potential signaling effect from executive deferral behaviors. Since corporate executives in most firms are likely to have informational advantages relative to outside directors, the directors may interpret deferrals by the firm's executives as informed signals of the firm's future prospects. Thus, we predict director equity deferrals to be positively associated with the deferrals made by corporate executives. ${ }^{17}$ We measure executives' deferral behavior with a dummy (i.e., Exe_Deferred) equal to one if the

\footnotetext{
${ }^{17}$ It may also be the case that executives and directors share similar information about the firm, leading to similar deferral choices. We find results consistent with this conjecture in robustness tests described in Section 4.6.
} 
firm's CEO and/or CFO defer any compensation in the year. ${ }^{18}$ As for the director equity deferrals, we identify deferral transactions by CEOs and CFOs through the derivative and security type and relationship fields in Thomson Insiders Data.

Finally, Benartzi (2001) and Choi et al. (2003) find that employees are more likely to invest their saving plan contributions in their firms' stock following periods of good stock market performance. In contrast, empirical studies indicate that insider traders are contrarian investors who buy firm stock when past returns have been lower (e.g., Piotroski and Roulstone 2005; Jenter 2005; Ravina and Sapienza 2009; Lakonishok and Lee 2001). We therefore examine the influence of firm past performance by including the firm's market-adjusted annualized stock returns over the prior two years (i.e., Stock Returns $t_{-2, t-1}$ ).

Table 4 - Panel B reports descriptive statistics on the executive deferrals and stock performance variables. Across all years, about 9\% of the firm's CEOs and/or CFOs registered at least one deferral transaction. The average firm's market-adjusted stock returns over the next year are about $9.2 \%$, and approximately $9.4 \%$ over the period up to the year the director's current mandate concludes. Finally, sample firms report mean past market-adjusted stock returns of about $8.6 \%$ over the prior two years.

\subsection{Personal characteristics}

In addition to firm-level factors such as the contractual features of the director compensation plans and future firm performance, we expect several personal characteristics to affect directors' equity deferral choices. We capture three sets of director-specific characteristics at the time the deferral options are offered. The first set includes proxies for the directors' existing ownership and professional profile inside the firm. First, we expect outside directors who already have a significant fraction of their wealth invested in the firm to defer lower amounts into equity because of under-diversification concerns. Consistent with this hypothesis, related research on insider trading finds that employees are less likely to buy firm shares when they already hold large stock holdings in the firm (e.g., Ke et al., 2003; Huddart el al., 2007; Huddart and Ke, 2007; Kallunki et al., 2009). \% Sharesheld measures the proportion of the firm's common shares outstanding owned by the director at the end of the prior year. Moreover, if directors use the equity deferrals as an alternative to open market purchases of the company's stock, we expect equity deferral values to be negatively associated with the presence of director open market purchases. Acquisition indicates whether the director registers open market

\footnotetext{
18 As noted earlier, executive deferred compensation plans usually allow the executives to defer both cash and equity pay into equity. Since public disclosures do not allow disentangling the proportion of cash compensation that is deferred, the registered transactions by CEOs and CFOs can represent a combination of equity and cash deferrals.
} 
purchases of the firm's common stock in the year. ${ }^{19}$ We also add a control for whether the director already meets the firm's ownership guidelines (if any are in place). Met Guidelines equals one if the number of shares held by the director is equal to or larger than the minimum number of shares required by the guidelines. ${ }^{20}$ If directors use equity deferrals to meet ownership guidelines, we expect directors who already meet the required ownership levels to defer less into equity. Finally, we add two controls for the director's past and future horizon in the firm, because directors can usually further defer previously deferred compensation and access the deferred compensation upon termination of directorship on the board. Tenure measures the number of directorship years at the firm. Horizon measures the number of years until the termination of current directorship, measured as the difference between the year in which the director ends her current board mandate and the current year.

The second set of measures includes two proxies for the director's wealth diversification status. Other Boards is the number of other boards the director serves on. Executive indicates whether the director is an executive (i.e., CEO and/or CFO) in another firm. All else equal, we predict outside directors who hold more diversified portfolios (i.e., directors sitting on multiple boards and executives in other firms) to be more willing to defer into the firm's equity. Finally, prior studies on the allocation of retirement funds and insider purchases indicate that these decisions are significantly associated with the insider's age and gender (e.g., Eaton and Rosen, 1983; Choi et al., 2003). To examine these associations in our setting, we include two additional variables capturing these director attributes in our models.

Table 4 - Panel C reports descriptive statistics on director personal characteristics. Sample directors report average ownership levels of about 0.16 basis points. About $9 \%$ of directors make open market purchase of the company's stock in the year, and 71\% already meet the required minimum ownership levels (if any are in place). Sample directors have an average directorship tenure in the firm of about eight years and a directorship horizon of almost two years before current service termination. In terms of wealth diversification, sample directors serve on at least one other board and 18\% are executives in other firms. Average director age is 61 years and $15 \%$ of sample directors are females.

\footnotetext{
${ }^{19}$ We identify directors' open market purchases by requiring the "trancode” field in Thompson Insider to equal " $\mathrm{P}$ ” and the "sectype" or "derivative” fields to equal "ORD” (i.e., Ordinary Shares) and "COM” (i.e., Common Stock). 20 Among the 1,715 plans with reported ownership guidelines for directors, 337 plans specify the required ownership levels as the minimum number of shares the directors must hold, while the remaining 1,378 plans specify the required levels in dollar values or as a multiple of the annual cash retainer. The Met Guidelines variable for these firms is computed by converting the minimum required ownership levels from dollar values to shares equivalents (by dividing the dollar value of the guidelines by the firm's year-end closing price) and comparing these amounts with the number of shares held by directors at the end of the year.
} 


\subsection{Univariate results}

Table 5 reports mean comparison tests between the sub-samples of directors who elected to defer (at least some) cash compensation into equity between 1999 and 2009 (i.e., 9,935 deferring director-years) and all other directors who received similar equity deferral options but did not exercise them (i.e., 31,360 non-deferring director-years). A number of significant differences emerge. Deferring directors receive higher average cash compensation $(\$ 57,000$ vs. $\$ 53,700$ ) and higher proportions of total equity pay (51\% vs. $49 \%$ ) compared to non-deferring directors. Deferring directors are also more likely to be subject to ownership guidelines (25\% vs. $21 \%)$ and to receive premiums for deferrals made into equity (12\% vs. $7 \%)$. On the other hand, the two groups do not differ significantly in their likelihood of receiving the option to defer into alternative investment accounts. Deferral likelihood also varies with the firm's past performance and the expectations directors may have regarding the firm's future prospects. Directors are more likely to defer in years in which the firm's CEO and/or CFO elect to defer into equity (20\% vs. 6\%). Consistent with contrarian strategies, directors are more likely to defer in years following poor performance and preceding significant stock price improvements.

Deferring and non-deferring directors also differ significantly in many personal characteristics. Consistent with diversification arguments, deferring directors, on average, hold smaller proportions of the firm's common shares outstanding $(0.11 \%$ vs. $0.18 \%)$, are less likely to already meet required ownership levels (68\% vs. $73 \%$ ), and less likely to perform open market purchases of the company's stock during the year (8\% vs. 9\%). Deferring directors sit on a larger number of other boards (1.3 vs. 1.1 boards) and are more likely to be executives in other firms (21\% vs. $17 \%)$. Deferring directors also tend to have shorter tenures in the firm (7.8 vs. 8.1 years) and shorter horizons before the end of their current service on the board (1.7 vs. 1.8 years). We find no significant differences in age and gender across the two groups.

We find similar results in untabulated analyses that compare two sub-samples of directors who always defer and directors who never defer in the years when they receive the option to. Out of the 41,295 director-firm-years in our sample, 3,463 observations pertain to directors who always defer and 24,589 pertain to directors who never defer. The remaining 13,243 observations relate to directors who defer at least once over their directorship at the firm. One advantage from including all three sub-samples of "always," “at-least-once,” and "never” deferring directors in our analyses is to exploit the within- and across- directors variation in personal and firm characteristics, such as time-varying features that might drive the directors to elect to defer in some firm-years but not others. 


\subsection{Multivariate results: overall sample}

We investigate the determinants of director equity deferrals in Table 6. The table reports results from OLS models examining the total dollar amounts the director deferred for the year. ${ }^{21}$ We compute the total deferred values as the sum of the values of all equity deferral transactions the director recorded in the year. By construction, equity deferral values are set to zero for directors not reporting equity deferral transactions in the year. The model in Column I regresses the value of the directors' equity deferrals on our set of hypothesized determinants plus firm fixed-effects. We include firm fixed-effects to control for time-invariant firm characteristics and provide tests for differences in director-level characteristics across directors serving the same firm and facing the same institutional environment. Column II replicates the model after including the Inverse-Mills ratio from the logit estimates in Table 2 - Panel B for the firm's choice to offer equity deferral options to directors. We report these results to mitigate concerns about omitted firm characteristics driving both the existence of equity deferral options and directors' deferral elections. ${ }^{22}$ To control for autocorrelation in the errors, regression coefficients are estimated by clustering standard errors by the directors' personal identification numbers (i.e., the "did” field in RiskMetrics). All models include controls for the logarithm of the firm's market value of equity, the firm's market-to-book ratio, and the standard deviation of the firm's stock returns over the prior two years to control for differences in size, growth opportunities and stock volatility across firms.

Results across both columns indicate that director equity deferrals are significantly associated with features of the director compensation plan. Controlling for the level of cash deferrable for the year and the size of the premiums for deferrals made into equity, equity deferral values are positively associated with the pre-deferral director compensation delivered in equity. This result supports the hypothesis that the perceived under-diversification costs brought about by the deferrals are lower for directors already committed to compensation contracts with higher equity incentives. The presence of ownership guidelines and alternative cash investment options are only weakly associated with the deferred amounts.

Consistent with information arguments, we find strong evidence that directors condition their deferral decisions based on expectations they may have regarding the firm's future stock market performance. Directors defer larger amounts in years in which the firm's CEO and/or

\footnotetext{
${ }^{21}$ We reach similar conclusions when we estimate tobit modes for the percent of the annual cash that was deferred and when we replace the dollar deferred amounts with a dummy for the director's choice to defer at least part of the annual cash pay into equity in logit models. Together, these results are consistent with the statistics presented in Table 3 suggesting that, when electing to defer, deferring directors choose to convert relatively large amounts of the deferrable cash into stock.

${ }^{22}$ We acknowledge that this can only be a partial correction for selection since we are missing an exogenous instrument in our logit estimates for the firm's choice to offer equity deferral options to directors.
} 
CFO defer compensation into equity. A significant positive association also emerges between equity deferral values and the firm's market-adjusted returns over the period until the director becomes eligible to cash in the equity values of the deferrals. Results are similar if we replace the director-specific Stock Returns horizon variable with the (more generic) variable measuring the firm's market adjusted returns over the next year (i.e., Stock Returns ${ }_{t+1}$ ). These results support the conjecture that, at the time they make their elections, directors believe their firms will realize significant stock market performance improvements, and that such improvements will last until they will become eligible to cash in the equity. ${ }^{23}$ Finally, the coefficients on the firm's past returns are negative and significant. This evidence suggests that, consistent with contrarian strategies, directors defer larger amounts after years of lower returns.

Moreover, the fact that the existence of executive deferrals in the year remain significant after controlling for future firm performance suggests that the deferrals by firm executives capture some additional information the directors rely upon when making their deferral elections. In untabulated tests, we investigate whether this result is driven by the possibility that executives and directors share a similar information set about the firm's future prospects (leading to similar deferral choices), rather than simply mimicking the executives. For this purpose, we replace the Exe_Deferred variable with an alternative indicator variable capturing whether the executive deferrals occurred any time before the director's deferrals. The variable measures whether the earliest deferral transaction registered by the firm's CEO and/or CFO occurred any time in the year before the earliest deferral transaction registered by the director. When we use this alternative measure in our models, the variable is no longer associated with the directors' equity deferrals. This result suggests that executive and directors share similar information about the firm (and defer accordingly), rather than directors simply mimicking prior deferrals made by the firm's executives because of some form of information disadvantage.

Proxies for the directors' ownership profiles inside the firm and wealth diversification status are also significant predictors. Consistent with portfolio diversification arguments, deferral values are negatively associated with the director's existing ownership levels in the firm and positively associated with proxies for the director's outside wealth diversification (i.e., number of other boards and whether the director is an executive elsewhere). Likely due to redeferrals, deferral values are positively associated with the director's board tenure in the firm, but not significantly associated with the number of years remaining before the end of the

\footnotetext{
${ }^{23}$ We find similar results over a sub-sample of deferring directors with directorship horizons longer than one year in classified boards. Average (median) directorship horizon for these directors is 2.61 (3) years. In untabulated analyses we find that, for this sub-sample of deferring directors, the buy-and-hold Stock Returnshorizon are higher than the firm's one-year ahead returns, consistent with the directors conditioning their deferral choices upon their expectations on the firm's stock market performance over their remaining directorship at the firm.
} 
director's current mandate. We observe no significant age effects, but find that female directors, on average, defer lower amounts compared to male directors. All results are robust if we restrict the sample to firms with at least one deferring director in the year.

\subsection{Sub-sample of multiple-board directors}

One potential concern with our analyses is the existence of some unobservable director personal characteristics that are likely associated with equity deferral choices but are not adequately captured in our models, such as the directors' outside wealth and/or relative risk aversion. To moderate concerns about the effects of such omitted characteristics, we test our models over a sub-sample of directors who serve on multiple firms offering equity deferral options between 1999 and 2009. This sub-sample is a particularly powerful setting for our analyses because those unobservable characteristics likely associated with deferral choices are held constant across all boards the director serves on in a given year. Moreover, since multipleboard directors may elect to defer in some firms but not in others, the sub-sample provides a quasi-experimental setting to assess the effects of the various contractual and firm characteristics we expect to impact the decision to defer, such as the information the directors may have regarding the firm's future performance.

We identify our sub-sample of multiple-board directors based on the directors' identification numbers in RiskMetrics, and flag cases of multiple-directorship if a director appears in more than one firm in a given year. The sample of multiple-board directors includes 3,341 distinct directors (about $41 \%$ of directors in the sample) serving on more than one board between 1999 and 2009. The average director sits on 2.7 distinct boards in a year and elects to defer in only $27 \%$ of the boards (5,450 deferring vs. 14,651 non-deferring director-firm-years).

Table 7 replicates the analyses in Table 6 using the sub-sample of directors who serve on multiple firms offering equity deferral options between 1999 and 2009. We continue to find that the equity deferrals are positively associated with the proportion of the pre-deferral director compensation paid in equity. Deferred amounts are larger when directors have longer tenure (because of re-deferrals) and smaller when directors already own a significant fraction of the firm's shares. Multiple-board directors who are executives elsewhere also defer larger amounts. The opposite remains true for female directors. Most importantly for our study, we continue to find strong evidence that directors condition their deferral elections on their expectations regarding future firm performance. Multiple-board directors defer larger amounts in years in which the firm's executives defer into equity and in years preceding significant stock market improvements. Analyses in Section 5 address whether these directors used the deferrals to trade 
upon private information by comparing the abnormal returns these directors realize from their deferrals to the returns they would have realized in those firms where they elect not to defer.

\subsection{Sub-sample of executive directors}

For some outside directors, the payments for board services may be so small relative to their outside wealth that the equity deferrals may become relatively irrelevant choices. This is expected to be particularly true for directors who are executives at other firms. To further address concerns about the economic relevance of the deferrals relative to the directors' unobservable outside wealth, we exploit the sub-sample of directors who are executive at other firms (i.e., 7,514 director-firm-years, 2,094 deferring and 5,420 non-deferring observations) to collect information about their annual compensation at their primary employers.

One field in RiskMetrics (i.e., the “priemp” field) provides the names of outside directors' main employers. We manually match the company names in this field to the "coname” field on ExecuComp to retrieve compensation data for the executive directors in our sample. We next match the directors' first and last names as reported in RiskMetrics to the executive's first and last names in ExecuComp. One potential limitation to this matching is that a director must be one of the five highest-paid executives in the firm in order to appear in ExecuComp. The process yields annual salary and total compensation data (i.e., sum of salary, other short-term compensation components, value of the restricted shares and stock option grants and any other annual pay) for 1,198 deferring and 2,833 non-deferring director-firmyears, corresponding to a relatively representative $57 \%$ and $52 \%$ of the deferring and nondeferring director observations in our original executive directors’ sample.

We conduct two additional analyses with these data. First, we compute the value of the directors' deferrals as a proportion of their annual salary and total compensation at their primary employers. Untabulated statistics indicate that the equity deferrals registered by executive directors in a year represent about $23 \%$ of the salary and $6 \%$ of the total compensation these directors received at their primary employers in that year. Since S\&P1500 executives most likely represent the wealthiest group of outside directors in our sample, ${ }^{24}$ these findings moderate concerns that the deferrals represent insignificant economic amounts and proportions of the directors' annual wealth. Second, we re-estimate our models using the sub-sample of executive directors with available salary and total annual compensation amounts (i.e., 4,031 director-firm-years). In untabulated models that control for the annual salary or total

\footnotetext{
${ }^{24}$ Average (median) salary and total pay levels for sample executive directors with available compensation data on ExecuComp are about $\$ 800,000(\$ 817,000)$ and $\$ 6,200,000 \quad(\$ 4,500,000)$, respectively. Both amounts are significantly higher than those reported by the average executive in ExecuComp over our sample period, primarily because our sample of executive directors mostly includes CEOs and CFOs at S\&P 500 firms.
} 
compensation (in separate specifications), we continue to find significant associations between the deferrals and variables capturing: a) whether the firm's executives engaged in similar transactions; b) the firm's future stock market performance; and c) the director's existing ownership in the firm. Interestingly, premium amounts still act as strong predictors of the equity deferrals made by this sub-sample of wealthier directors. ${ }^{25}$

\section{Trading performance of director equity deferrals}

\subsection{Abnormal returns}

In this section, we investigate the trading performance of sample directors' equity deferrals. Using an approach similar to Ravina and Sapienza (2009), we measure the level of insider information outside directors exploit through their deferrals by computing the cumulative abnormal returns the directors realize from these transactions. Table 8 reports results for cumulated abnormal returns measured at various horizons. RET $(\mathrm{t}+60), \operatorname{RET}(\mathrm{t}+180)$, and $\operatorname{RET}(\mathrm{t}+360)$ are the buy-and-hold returns over the $+60,+180$, and +360 days following the equity deferral transactions dates, respectively. RET(horizon) cumulates returns between the equity deferral transaction dates and the end of the year in which the director's current mandate ends. RET(final) cumulates returns between the equity deferral transaction dates and the end of the year in which the director's last mandate at the firm ends. We estimate two abnormal return measures. Market-adjusted returns are the difference between the firm's stock returns and the market returns, where the S\&P500 Index is used as a proxy for the market portfolio. Benchmark-adjusted returns are the difference between the firm's stock returns and the returns predicted by the size, book-to-market, and momentum model as in Daniel et al. (1997).

Across all measurement windows and estimation methods, deferring directors exhibit significant abnormal returns from their equity deferrals. Average market-adjusted (benchmarkadjusted) returns for the overall sample equal 2.5\% (0.5\%), 7\% (1.2\%), and 13.7\% (1.6\%) over the $+60,+180$, and +360 days following the deferral transaction dates, respectively. All returns are statistically different from zero and remain significantly positive at longer horizons. Multiple-board directors electing to defer in some firms but not others realize market-adjusted returns that are similar to the overall sample, but benchmark-adjusted returns that are significantly higher at longer horizons. ${ }^{26}$

\footnotetext{
25 The significant effect from available premiums is consistent with Adams and Ferreira's (2008) finding that outside board members respond to the very small monetary incentives provided by board meeting attendance fees.

${ }^{26}$ The long-window returns associated with director equity deferrals are consistent to those found in other studies. Ravina and Sapienza (2009) investigate and find significant returns over horizons up to +180 days. In a more recent paper, Cao et al. (2015) also finds that directors who are socially connected to the firm's executives realize significant returns over 180 day windows. These results suggest that the market does not fully impound the information contained in outside directors’ insider trading filings, even over relatively long windows.
} 
To investigate whether directors realize abnormal returns based on insider information, we next compare the returns deferring directors realize from their deferrals to the returns nondeferring directors would have realized if they had exercised their deferral options at their firms. If directors' deferral decisions are based on insider information regarding the firm's future prospects, we expect the returns to be significantly larger for deferring directors. Alternatively, if deferral decisions reflect factors other than insider information, we should see no significant differences in subsequent returns across the deferring and non-deferring groups. One issue with this analysis is choosing a date on which non-deferring directors would have deferred in those firms in which they decide not to. Table 8 - Panel A compares the abnormal returns of sample directors' equity deferrals to the returns non-deferring directors would have realized if they had exercised their options on the firm's annual board meeting date. We use the annual board meeting date because this is the date newly-elected directors can exercise their first deferral options and is likely to be a period when board members receive substantial insider information to trade upon. Results, however, are similar if we assume that non-deferring directors would have deferred before the beginning of the year, which corresponds to the spike in deferral dates as reported in Figure 1. Across both market- and benchmark-adjusted abnormal return measures, deferring directors realize significantly higher returns at all horizons. These results suggest that the returns deferring directors earn from their transactions are the result of directors conditioning their deferrals based on some form of insider information. ${ }^{27}$

Table 8 - Panel B replicates the analyses using the sub-sample of multiple-board directors electing to defer in some firms but not in others, thereby controlling for director effects. For this sub-sample, we compare the abnormal returns these directors realize from their deferrals to the returns they would have realized if they had exercised their equity deferral options at other firms. Similar to the analyses in Table 8 - Panel A, we assume that the deferrals would have occurred on the annual board meeting dates of those firms where the directors do not exercise their deferral options. Across both abnormal return measures, the multiple-board directors realize significantly higher returns when they elect to defer, compared to when they do not. The results are qualitatively similar if we assume that the directors would have deferred in the non-deferring firms before the beginning of the year. The results from the multiple-board sub-sample provide further support for the argument that sample directors used their deferral transactions to exploit insider information.

27 Consistent with these arguments, in untabulated tests examining director turnovers, we find that deferring directors tend to leave their firms in years preceding significant stock price declines. This result is robust across both abnormal returns measures. 


\subsection{Cross-sectional variation in returns}

In this section, we investigate various factors potentially associated with the magnitude of the abnormal returns directors realize from their deferral transactions. We estimate the effect of two sets of variables. The first set of measures is aimed at capturing variation in directors' ability to acquire (and trade upon) relevant information about the firm. These variables include measures for the firm's overall governance quality and information environment, as well as other mechanisms that previous studies have shown to affect outside directors' information access and monitoring abilities, such as the proportion of insiders on the board, board size, committee memberships and attendance at board meetings. We measure a firm's governance quality based on the Gompers, Ishii, and Metrick (2003) Governance Index, and categorize a firm as having weak governance if the index falls into the top quartile of sample distribution. ${ }^{28}$ We measure a firm's information environment by the number of analysts following the firm and the number of forecasts issued by the firm's executives in the year. Higher quality governance firms may have better mechanisms in place that allow the market to receive timely information about the firm. Similarly, higher analyst coverage and frequency of management forecasts may translate in smaller information gaps between firm insiders and the market. As a consequence, we expect outside directors to be better able to exploit relevant private information when the firm has weaker governance, less analysts following and less frequent management forecasts. We also expect directors' information access to be facilitated when the proportion of insiders on the board is higher. Moreover, if the level and type of outside director involvement in board activities influence information acquisition, returns may vary with the directors' attendance records and type of committee memberships.

The second set of variables is used to test whether the realized returns also vary with specific features of the director deferral plan, and whether directors use the equity deferrals as a tax-advantaged substitute for open-market purchases of the company's stock. We expect directors to require lower returns from their deferrals when the deferral plans have features, such as premiums, that make the deferrals relatively cheaper, and/or when other contractual contingencies make these transactions relatively less discretionary, such as the existence of minimum ownership guidelines for directors. Across all sample firms and years, deferring

\footnotetext{
28 The Governance Index by Gompers, Ishii, and Metrick (2003) measures a firm’s governance quality by counting the number of governance provisions a firm has that restrict shareholder rights. More governance provisions, and thus a higher Governance Index, proxy for weaker governance. The original list of governance provisions in the Governance Index included 24 distinct items. Since 2007, RiskMetrics only collects a subset of these provisions. In order to compute a governance quality proxy valid across all years in our sample, we calculate the index by restricting the count to those provisions available in both the pre- and post- 2006 RiskMetrics files. The index computed using this sub-set of provisions has a correlation of about $85 \%$ with the index computed using all 24 of the original provisions. Our results in Table 9 remain highly significant if we restrict the analyses to the 1999-2006 sub-period with available data to compute the index based on all 24 original provisions.
} 
directors made only 1,967 open market purchases compared to 8,124 by non-deferring directors. These numbers suggest that deferring directors used the deferrals as a substitute for open market purchases. If directors use the deferrals as an alternative purchase mechanism purely because of tax benefits, we expect the returns to be significantly lower in the presence of higher personal income tax rates (since the tax savings from the deferrals would make the after-tax returns higher). If, on the other hand, directors use the deferrals for reasons other than tax advantages, we expect no association between the returns and the size of the tax savings.

Table 9 provides results from these analyses. Panel A (Panel B) reports results examining cumulated market-adjusted (benchmark-adjusted) returns at $+60,+180$, and +360 days following the equity deferral transaction dates, as well as for the period up to the end of the director's current mandate (RET(horizon)). We estimate all models including firm fixed-effects, clustering standard errors at the director level, and controlling for the size of the transactions. Across most measurement windows and estimation methods, the abnormal returns directors realize from the deferrals are higher in firms with weaker governance, smaller boards, and boards with higher proportions of insiders, and lower in firms with higher analyst coverage and more frequent management forecasts. These results provide strong evidence that directors earn larger returns in settings where their ability to acquire and trade upon insider information is higher. We find no evidence that committee memberships or directors' attendance records are significantly associated with the returns. We also find that, at longer horizons, the abnormal returns are negatively associated with the size of the premiums and the existence of minimum ownership guidelines for directors. With one exception (market-adjusted RET(horizon)), returns do not vary significantly with the personal tax rates. Together, these results suggest that, aside from information reasons, the returns do also vary with director compensation plan features. We find no evidence that sample directors used the deferrals as an alternative to open-market purchases because of tax benefits.

\subsection{Opportunistic timing}

To further address the factors contributing to the abnormal returns deferring directors realize from their transactions, in this section we investigate whether the equity deferrals were timed opportunistically. We first look at whether the deferrals were backdated. Following the approach in Lie (2005) and Heron and Lie (2007), we first examine the reporting gaps between the "trandate" (the date of the transaction) and "secdate" (the date in which the director's Form 4 was submitted to the SEC) fields in Thompson Insider. Untabulated statistics indicate that the average (median) number of trading days between the two dates is 29 (2). About $73 \%$ of the deferrals were reported to the SEC within five trading days of the transactions, with about $64 \%$ 
reported within two days. The reporting gaps are much smaller after August 29, 2002, when the SEC changed the reporting regulation for Forms 4 filings. ${ }^{29}$ Average (median) trading days between the "trandate" and "secdate" fields for deferral transactions occurring after the new regulation are 7 (2), with about $83 \%$ of the deferrals reported within two days. Heron and Lie (2007) find similar patterns in reporting gaps for their sample of executive stock option grants before and after the new regulation. When we plot the cumulative daily abnormal returns over the $(-30,+360)$ period around the deferral transaction dates (see Figure 2), the returns do not show the typical $\mathrm{V}$-shape patterns associated with backdating, with negative abnormal returns before the transactions and positive abnormal returns afterward. These results provide no evidence of backdating in our sample of director equity deferrals.

We next investigate whether the returns deferring directors realize come from strategic timing of the deferral transactions during periods when open market purchases of the firm's shares would violate Rule 10b5 trading restrictions. As described in Section 2, Rule 10b5-1 creates a "safe harbor" in which directors, through the adoption of a pre-planned, 10b5-1 compliant deferral plan, can trade a company's securities even during periods when they possess material non-public information. Various loopholes in the rule, including the ability to cancel pre-planned deferrals on short notice and without penalties, provide directors with the opportunity to exploit insider information while remaining under the protection of 10b5-1. Since the firms in our sample allow for both pre-scheduled and unscheduled deferrals (which are still subject to blackout trading restrictions), the finding that a significant fraction of the transactions occurs during blackout periods would provide evidence that sample directors effectively used 10b5-1 compliant deferral plans as a mechanism to conduct stealth insider trading.

We follow Bettis, Coles, and Lemmon (2000) and define the -47 to +2 trading days relative to quarterly earnings announcements as blackout days and the +3 to +12 trading days as non-blackout days. To investigate the use of the equity deferrals as an alternative mechanism to conduct stealth insider trading, we calculate average transaction sizes and values of the directors' equity deferrals and open market purchases during blackout and non-blackout periods, respectively. Results from these analyses are reported in Table 10 and Figure 3. The reported number of transactions during blackout and non-blackout periods indicates that about $66 \%$ of the director equity deferrals in our sample fall within the -47 to +2 days around quarterly

\footnotetext{
${ }^{29}$ In response to changes to Section 16 of the Securities and Exchange Act of 1934 mandated by the SarbanesOxley Act, the new regulation requires Forms 4 to be filed before the end of the second business day following the day of a transaction resulting in a change in beneficial ownership. This category includes stock option grants, restricted stock grants and acquisitions of stock units under non-tax qualified deferred compensation or other dividend and interest reinvestment plans (see https://www.sec.gov/rules/final/34-46421.htm). However, the SEC has adopted special limited deferred reporting rules (up to five business days depending upon circumstances) for 10b5-1 transactions, including deferred compensation plan investments that fall within the scope of 10b5-1 plans.
} 
earnings announcement dates. Table 10 - Panel A compares the trading sizes and values of the equity deferrals and open market purchases by all outside directors in our sample. Table 10 Panel B replicates the comparisons over the sub-sample of firms with at least one deferring director in the year. Although we observe significant decreases in average transaction sizes for both types of transactions during blackout windows, the average transaction size of equity deferrals is substantially higher than that of open market purchases during black-out days. We observe similar patterns in transaction values. The average deferral (open purchase) transaction value declines from $\$ 20,302(\$ 30,101)$ during non-blackout days to $\$ 15,691(\$ 8,203)$ in blackout days across all firms. These results are stronger in the sub-sample of firms with at least one deferring director, where the average deferral transaction size is about 85 basis points compared to an average size of 12 basis points for open market purchases, with a peak at 17 trading days before the quarterly earnings announcement. For this sub-sample, the average deferral (open purchase) transaction value decreases from $\$ 42,769(\$ 17,659)$ during nonblackout days to $\$ 31,360(\$ 4,606)$ in blackout periods. Overall, these findings indicate that outside directors use equity deferrals as an alternative purchase mechanism during blackout periods, and that the returns deferring directors realize come, for a significant fraction of the transactions, from the exploitation of material insider information before quarterly earnings announcements. This evidence is consistent with ongoing SEC concerns that directors may be using deferral plans set in accordance with 10b5-1 to circumvent blackout period trading restrictions.

\section{Summary and conclusions}

This study investigates the determinants and trading performance of outside directors' equity deferrals, which represent the choice to convert part or all of their annual cash compensation into deferred company stock. We examine director equity deferrals using a handcollected sample of S\&P1500 firms that allowed outside board members to defer their cash compensation into equity between 1999 and 2009. We first investigate the factors influencing a firm's choice to offer equity deferral options to directors. Results indicate that the options are used by larger firms as a substitute for standard director stock option and share grants and as a means to allow directors to increase their existing ownership in the firm. We next focus on the determinants and trading performance of director equity deferrals. Our evidence that directors condition their deferrals based on future stock market performance, that directors on multiple boards selectively choose where to defer, and that the equity deferrals generate significant abnormal returns, suggest that directors can use the deferral transactions to trade upon material insider information. Although prior studies find that independent directors earn abnormal returns 
when purchasing their company's stock, they provide no evidence on how directors can circumvent SEC Rule 10b-5 when making informed trades. Our blackout results provide strong evidence that outside directors can use 10b5-1 deferral plans to conduct stealth insider trading.

Our study leaves open two issues. First, since the deferred amounts can still represent a fairly small proportion of most directors' total outside wealth, our results raise the question about why directors would risk violating SEC rules with these transactions. The availability of Rule 10b5-1's defence against insider information claims provides one explanation, but future studies can shed additional light on the firm's and contractual conditions influencing directors' insider trading incentives. Second, consistent with other studies on outside directors' trades, we find that the market does not fully impound the information content of director equity deferrals, even at longer horizons. These issues remain questions for future research. 


\section{References}

Adams, R., D. Ferreira, 2008. Do directors perform for pay? Journal of Accounting and Economics 46: 154-171.

Baldwin, S., L.I., Wilson, 1998. Beyond stock-related compensation for directors. Corporate Board 19: 15-20.

Benartzi, S., 2001. Excessive extrapolation and the allocation of 401(k) accounts to company stock. The Journal of Finance 56: 1747-1764.

Benartzi, S., R. Thaler, S. Utkus, and C. Sunstein, 2007. The law and economics of company stock in 401(k) plans. Journal of Law and Economics 50: 45-79.

Bettis, J.C., J.L. Coles, M.L. Lemmon, 2000. Corporate policies restricting trading by insiders, Journal of Financial Economics 57: 191-220.

Campbell, C., M. Power, and R. Stover, 2006. Quid-pro-quo exchanges of outside director defined benefit pension plans for equity-based compensation. Journal of Pension Economics and Finance 5: 155-174.

Cao, Y., D. Dhaliwal, Z. Li, Y.G. Yang, 2015. Are all independent directors equally informed? Evidence based on their trading returns and social networks. Management Science61: 795-813.

Choi, J., D. Laibson, B. Madrian, and A. Metrick, 2003. Employees' investment decisions about company stock. Pension Design and Structure: New Lessons from Behavioral Finance: 121-137

Cook, F.W. \& Co., Inc., 2012-2014. Director Compensation Report: Non-Employee Director Compensation Across Industries and Size. New York

Conference Board. 2006. Directors’ compensation and board practices in 2006. New York.

Cook and Wang, 2001. The informativeness and ability of independent multi-firm directors. Journal of Corporate Finance 17: 108-121.

Core, J. and W. Guay, 1999. The use of equity grants to manage optimal equity incentive levels. Journal of Accounting and Economics 28: 151-184.

Core, J., W. Guay, D. Larcker, 2003. Executive equity compensation and incentives: a survey. Economic Policy Review 9: 27-50.

Daniel, K., M. Grinblatt, S. Titman, R. Wermers, 1997. Measuring mutual fund performance with characteristic-based benchmarks, Journal of Finance 52: 1035-1058.

Demsetz, H., K. Lehn, 1985. The structure of corporate ownership: causes and consequences. Journal of Political Economy 93: 1155-1177.

Den Uyl, J.M. 1998. Voluntary deferred compensation plans: trends and issues in plan design. Benefits Quarterly (Third Quarter): 29-31.

Eaton, J., and H.S. Rosen, 1983. Agency, delayed compensation, and the structure of executive remuneration. Journal of Finance 38: 1489-1505.

Edmans, A., X. Gabaix, 2009. Is CEO pay really inefficient? A survey of new optimal contracting theories. European Financial Management 15: 486-496.

Fama, E. and K. French. 1997. Industry costs of equity. Journal of Financial Economics 43: 153 $-93$.

Fich, E.M., A., Shivdasani, 2005. The impact of stock-option compensation for outside directors on firm value. The Journal of Business 78: 2229-2254.Good, S., L. Hurtado, G. Lombardi, C. Schlaefer, B. Wong, 2013. Best laid plans gone awry: Practices for rule 10b5-1 trading. http://pillsburylaw.com/publications/best-laid-plans-gone-awrypractices-for-rule-10b5-1-trading plans.

Hermalin, B., and M. Weisbach, 1991. The effects of board composition and direct incentives on firm performance. Financial Management 20: 101-112.

Heron, R., and E. Lie, 2007. Does backdating explain the stock price pattern around executive stock option grants? Journal of Financial Economics 83: 271-295. 
Huddart, S.J., Ke, B., 2007. Information asymmetry and cross-sectional variation in insider trading. Contemporary Accounting Research 24: 195-232.

Huddart, S.J., Ke, B., Shi, C., 2007. Jeopardy, non-public information, and insider trading around SEC 10-K and 10-Q filings. Journal of Accounting and Economics 43: 3-36.

Jagolinzer, A., 2009. SEC rule 10b5-1 and insiders' strategic trades. Management Science 55: 224-239.

Jenter, D., 2005. Market timing and managerial portfolio decisions. Journal of Finance 60: 1903-1949.

Kallunki, J-P., H. Nilsson, and J. Hellstrom, 2009. Why do insiders trade? Evidence based on unique data on Swedish investors. Journal of Accounting and Economics 48: 37-53.

Ke, B., Huddart, S., and Petroni, K., 2003. What insiders know about future earnings and how they use it: evidence from insider trades. Journal of Accounting and Economics 35: 315346.

Lakonishok, J. and I. Lee, 2001. Are insider trades informative? Review of Financial Studies 12: 79-111.

Lie, E., 2005. On the timing of CEO stock option awards. Management Science 51: 802-812.

Linn, S.C., D., Park. 2005. Outside director compensation policy and the investment opportunity set. Journal of Corporate Finance 11: 680-715.

MCG Management Consulting Group, 1999. Survey of executive and outside director benefits 1999. New York.

McNeil, B.,J., 2009. Nonqualifield deferred compensation: a reader's digest review. Journal of Deferred Compensation 1-43.

Mercer Human Resource Consulting, 2003. Mercer director compensation snapshot survey results 2003. New York.

Mitchell, M., and E. Stafford, 2000. Managerial decisions and long-term stock price performance. Journal of Business 73: 287-329.

Murphy, K., 1999. Executive compensation, in O. Ashenfelter and D. Card, eds, Handbook of Labour Economics (New York: Elsevier/North-Holland).

National Association of Corporate Directors, 2004. Director compensation: purposes, principles, and best practices: A report of the NACD Blue Ribbon Commission. Washington.

Ofek, E., and D. Yermack, 2000. Taking stock: equity-based compensation and the evolution of managerial ownership. Journal of Finance 55: 1367-1384.

Piotroski, J., D. Roulstone, 2005. Do insider trades reflect both contrarian beliefs and superior knowledge about future cash flow realizations? Journal of Accounting and Economics 39: 55-81.

Pulliam, S., R. Barry, 2013. Directors take shelter in trading plans. Wall Street Journal, April 30.

Ravina, E. P. Sapienza, 2010. What do independent directors know? Evidence from their trading. Review of Financial Studies 23: 962-1003.

Ronald, D., H. J., Toppel. 1998. Using stock in corporate directors' deferral plans. Benefits Quarterly (Third Quarter): 18-23.

Ryan, H.E., R. A., Wiggins, 2004. Who is in whose pocket? Director compensation, board independence and barriers to effective monitoring. Journal of Financial Economics 73: 497-524.

Security and Exchange Commission, 2002. Ownership reports and trading by officers, directors and principal security holders (https://www.sec.gov/rules/final/34-46421.htm)

Security and Exchange Commission, 2006. Executive compensation and related person disclosure (http://www.sec.gov/rules/final/2006/33-8732afr.pdf)

Smith, C., R. Watts, 1992. The investment opportunity set and corporate financing, dividends, and compensation policies. Journal of Financial Economics 32: 263-292.

Yermack, D., 1995. Do Corporations Award CEO Stock Options Effectively? Journal of Financial Economics 39: 237-269. 
Yermack, D., 2004. Remuneration, retention, and reputation incentives for outside directors. The Journal of Finance 59: 2281- 2308 


\section{Appendix \\ Proxy statement descriptions of the deferred plans for outside directors}

From H\&R Block’s 2001 Proxy Statement:

"In accordance with the provisions of the H\&R Block Deferred Compensation Plan for Directors, eligible non-employee directors may defer receipt of their cash retainers and/or meeting fees. Gain and losses are posted to each director account in accordance with the participant's election among a fixed rate, variable rate and Company common stock investment alternatives. Units credited to a stock account are based upon the amount deferred and the market price of Company's stock. The value of each stock account at the time of the distribution will be based on the market value of the stock at that time." (Definitive Proxy Statement filed on $30^{\text {th }}$ July, 2001).

From Supervalu Inc.'s 2003 Proxy Statement:

“Directors may elect to defer payment of their directors' fees under one or more of the following arrangements: 1) Directors Deferred Compensation Plan and Executive Deferred Compensation Plan. Fees and quarterly interest are credited to an account for the director, until payment is made from the plan following retirement from the Board. 2) Non-Employee Directors Deferred Stock Plan. This plan is designed to encourage increased stock ownership among directors. Under the plan, a director may elect to have payment of all or a portion of the directors' fees deferred and credited to a deferred stock account. The Company then credits the director's account with an additional amount equal to $10 \%$ of the amount of fees the director has elected to defer and contributes the total amounts in the director's account to an irrevocable trust, that use the amounts to purchase shares of the Company common stock. [...] The common stock in each director's deferred stock account will be distributed to the director after the director leaves the Board. Until that time, the trust assets remain subject to the claims of our creditors". (Definitive Proxy Statement filed on $5^{\text {th }}$ May, 2003).

From First Community Bank’s 2005 Proxy Statement:

“The Company has adopted a Directors' Deferred Compensation Plan, or the Deferred Plan, that allows all directors of the Company and its subsidiaries, to elect by written notice to defer payment of all or a portion of their directors' fees, for the next succeeding calendar year into the Deferred Plan. The Deferred Plan permits participants to elect to have deferred amounts invested in a money market account or common stock of the Company. The Deferred Plan has been designed to comply with Rule 10b5-1 of the Securities Exchange Act of 1934, as amended. Participation in the Deferred Plan is voluntary and participants may change their elections annually, or otherwise as permitted by the Deferred Plan." (Definitive Proxy Statement filed on $16^{\text {th }}$ March, 2005).

\section{From Paxair Inc.’s 2008 Proxy Statement:}

"Under the Directors' Fees Deferral Plan, non-management directors may, before the beginning of a calendar year, elect to defer to a later date payment of some or all of the cash fees that may be earned in the upcoming year. A director fixes this deferred payment date when he or she makes his or her deferral election. A director also chooses whether the deferred fees will earn amounts based upon a "Cash Account", or a "Stock Unit Account." The Cash Account earns interest at the prime rate, while the value of the Stock Unit Account tracks the market price of the Company's common stock. Stock units provide directors the economic equivalent of owning the Company's stock, except that the units may not be transferred or sold and they do not provide any voting or other shareholder rights. The "Cash Account" is paid to the director in cash on the designated payment date. The "Stock Unit Account" is paid in shares of Company common stock." (Definitive Proxy Statement filed on $14^{\text {th }}$ March, 2008). 


\section{Table 1: Firms offering equity deferral options to outside directors (ExecuComp-RiskMetrics 1999-2009)}

The table presents the proportion of firms in the ExecuComp-Riskmetrics intersection over the period 1999-2009 (14,017 firm-years) offering to outside directors the option to defer cash compensation into equity in the year. Panel A reports the number and proportion of firms offering equity deferral options by year and S\&P Index (i.e., S\&P500, MidCap, SmallCap \& No Index). Panel B reports the number and proportion of firms offering equity deferral options by Fama-French (1997) 12-industry classifications and S\&P500 Index.

Panel A: By Year and S\&P Index

\begin{tabular}{|c|c|c|c|c|c|c|c|c|}
\hline \multirow[b]{2}{*}{ Year } & \multicolumn{2}{|c|}{ Overall Sample } & \multicolumn{2}{|c|}{ S\&P500 } & \multicolumn{2}{|c|}{ MidCap } & \multicolumn{2}{|c|}{ SmallCap/No-Index } \\
\hline & $\mathbf{N}$ & $(\%)$ & $\mathbf{N}$ & $(\%)$ & $\mathbf{N}$ & $(\%)$ & $\mathbf{N}$ & $(\%)$ \\
\hline 1999 & 386 & (30.5\%) & 162 & (46.1\%) & 61 & (30.8\%) & 163 & $(22.7 \%)$ \\
\hline 2000 & 427 & (33.0\%) & 182 & $(50.0 \%)$ & 71 & (32.3\%) & 174 & $(24.6 \%)$ \\
\hline 2001 & 465 & (33.9\%) & 193 & (51.3\%) & 72 & (30.5\%) & 200 & (26.3\%) \\
\hline 2002 & 492 & $(37.8 \%)$ & 208 & $(57.3 \%)$ & 89 & (37.9\%) & 195 & $(27.7 \%)$ \\
\hline 2003 & 513 & (39.4\%) & 230 & $(60.2 \%)$ & 95 & $(37.2 \%)$ & 188 & $(28.2 \%)$ \\
\hline 2004 & 513 & (39.9\%) & 235 & $(60.7 \%)$ & 97 & $(36.5 \%)$ & 181 & (28.7\%) \\
\hline 2005 & 520 & $(40.7 \%)$ & 239 & $(60.5 \%)$ & 104 & (37.5\%) & 177 & $(29.3 \%)$ \\
\hline 2006 & 528 & (42.5\%) & 255 & $(62.3 \%)$ & 114 & $(40.6 \%)$ & 159 & $(28.9 \%)$ \\
\hline 2007 & 465 & $(40.6 \%)$ & 210 & $(60.2 \%)$ & 111 & (38.0\%) & 144 & $(28.6 \%)$ \\
\hline 2008 & 529 & $(42.0 \%)$ & 255 & $(61.6 \%)$ & 127 & $(39.4 \%)$ & 147 & $(28.0 \%)$ \\
\hline 2009 & 551 & $(43.1 \%)$ & 277 & $(63.1 \%)$ & 137 & $(39.4 \%)$ & 137 & $(28.0 \%)$ \\
\hline All Years & 5,389 & $(38.4 \%)$ & 2,446 & $(57.8 \%)$ & 1,078 & $(36.9 \%)$ & 1,865 & $(27.2 \%)$ \\
\hline \multicolumn{9}{|c|}{ Panel B: By Industry \& S\&P500 Index } \\
\hline & & \multicolumn{3}{|c|}{ Overall Sample } & \multicolumn{2}{|c|}{ S\&P500 } & \multicolumn{2}{|c|}{ All Other Firms } \\
\hline Industry & & $\mathbf{N}$ & & & $\mathbf{N}$ & $(\%)$ & $\mathbf{N}$ & $(\%)$ \\
\hline \multicolumn{2}{|c|}{ Non-Durable Consumer } & 371 & \multicolumn{2}{|c|}{$(41.4 \%)$} & 178 & $(59.3 \%)$ & 193 & $(32.4 \%)$ \\
\hline \multicolumn{2}{|c|}{ Durable Consumer } & 130 & \multicolumn{2}{|c|}{$(36.8 \%)$} & 38 & $(59.4 \%)$ & 92 & $(31.8 \%)$ \\
\hline \multicolumn{2}{|c|}{ Manufacturing } & 919 & \multicolumn{2}{|c|}{ (49.8\%) } & 340 & (70.7\%) & 579 & $(42.4 \%)$ \\
\hline \multicolumn{2}{|c|}{ Energy } & 169 & \multicolumn{2}{|c|}{ (30.5\%) } & 117 & $(44.5 \%)$ & 52 & $(17.9 \%)$ \\
\hline \multicolumn{2}{|l|}{ Chemicals } & 352 & \multicolumn{2}{|c|}{ (74.1\%) } & 133 & (83.1\%) & 219 & (69.5\%) \\
\hline \multicolumn{2}{|c|}{ Business Equipment } & 531 & \multicolumn{2}{|c|}{ (21.9\%) } & 286 & $(41.3 \%)$ & 245 & $(14.1 \%)$ \\
\hline \multicolumn{2}{|c|}{ Telecommunications } & 94 & \multicolumn{2}{|c|}{ (37.4\%) } & 59 & (55.7\%) & 35 & $(24.1 \%)$ \\
\hline \multicolumn{2}{|c|}{ Utilities } & 520 & \multicolumn{2}{|c|}{ (63.4\%) } & 272 & $(78.2 \%)$ & 248 & (52.5\%) \\
\hline \multicolumn{2}{|c|}{ Wholesale/Retail } & 588 & \multicolumn{2}{|c|}{ (35.1\%) } & 247 & (51.5\%) & 341 & $(28.5 \%)$ \\
\hline \multicolumn{2}{|c|}{ Healthcare } & 300 & \multicolumn{2}{|c|}{ (27.9\%) } & 181 & $(54.7 \%)$ & 119 & $(16.0 \%)$ \\
\hline \multicolumn{2}{|l|}{ Finance } & 937 & & & 405 & $(66.8 \%)$ & 532 & (36.1\%) \\
\hline Other & & 478 & & & 190 & $(47.9 \%)$ & 288 & $(24.7 \%)$ \\
\hline All Industı & & 5,389 & & & 2,446 & (57.8\%) & 2,943 & (30.1\%) \\
\hline
\end{tabular}




\section{Table 2: The choice to offer equity deferral options to outside directors}

The table presents analyses for the determinants of the firm's choice to offer equity deferral options to outside directors in the year. Panel A presents descriptive statistics of the hypothesized determinants. Panel B presents univariate comparisons between firms that offer equity deferral options to outside directors and firms that do not and results from a logit model for the firm's choice to offer equity deferral options to directors. Sample for this table is the the ExecuComp-RiskMetrics intersection over the period 1999-2009 with available data on the selected variables $\left(11,958\right.$ firm-years). We base $z$-statistics on standard errors clustered by firm. ${ }^{* * *},{ }^{* *},{ }^{*}$ indicate significance at $\mathrm{p}<$ $0.01, \mathrm{p}<0.05, \mathrm{p}<0.10$, respectively. All variables are defined in the text.

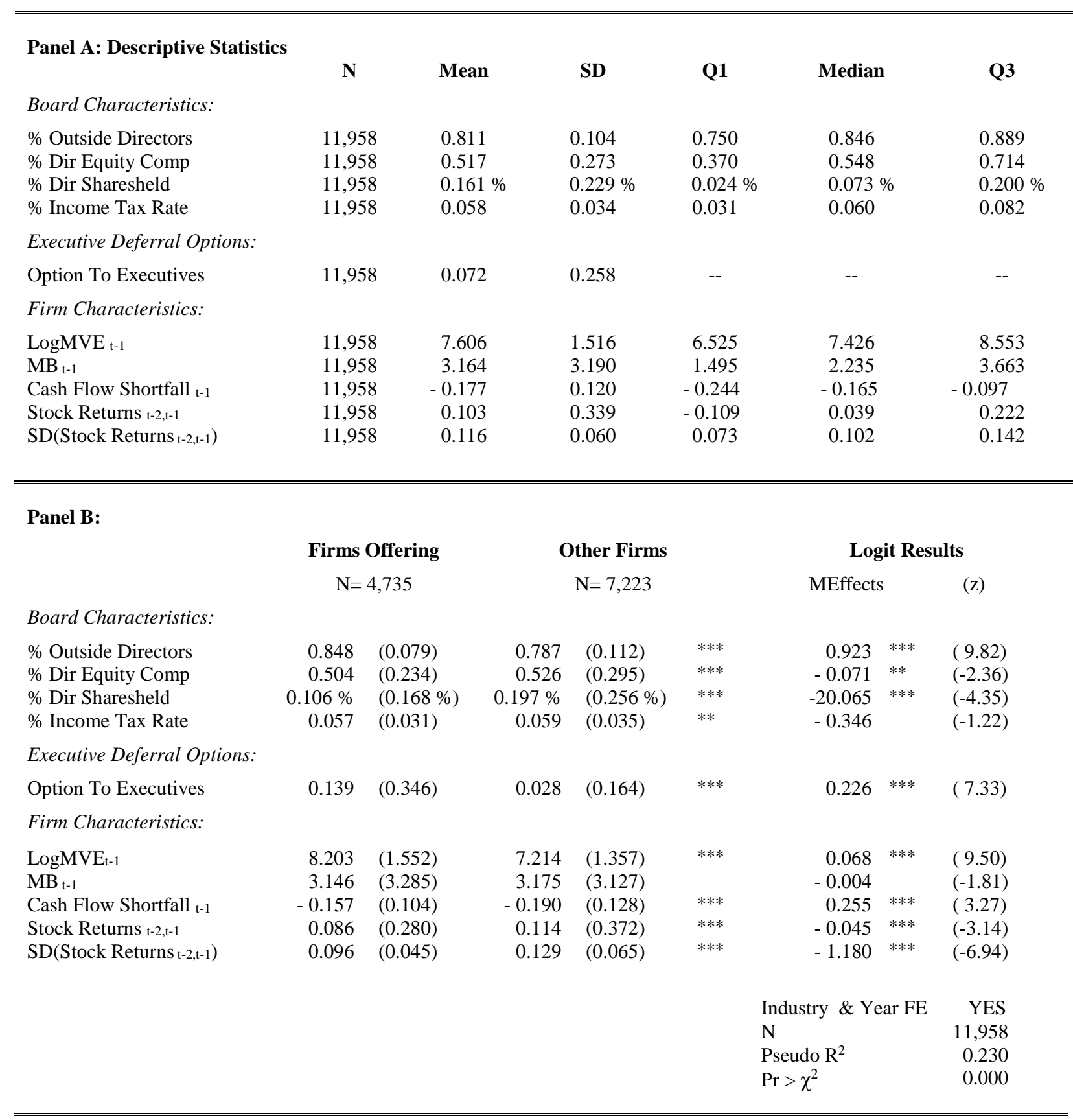




\section{Table 3: Descriptive statistics on director equity deferrals}

The table presents descriptive statistics on the equity deferral transactions registered by outside directors from the subset of ExecuComp-RiskMetrics firms allowing equity deferral options to directors over the period 1999-2009 with available director- and firm-level characteristics. The sample for this table consists of 2,078 firm-years with at least one deferring director and 9,935 directors-firm-years with equity deferral transactions as reported on the firm's SEC Forms 4 in Thompson Insider Filings Data. Panel A presents descriptive statistics on the number and proportion of outside directors who filed at least one equity deferral transaction at the firm. Panel B presents statistics on the number of deferral transactions, the amount deferred per transaction, and the total amount deferred in a year, expressed both in absolute value and as a proportion of the total cash compensation (i.e., the sum of annual retainer and meeting fees) to be earned by the director in the year. The dollar value of the deferrals equal the value of the deferred stock units on the day the transactions were filed, as reported in the "trandate" field in Thompson Insider Filings Data. The total dollar value that was deferred is computed as the sum of the values of all the deferral transactions the director filed in the year at the firm.

\begin{tabular}{|c|c|c|c|c|c|c|}
\hline \multicolumn{7}{|l|}{ Panel A: Deferring Directors } \\
\hline & $\mathbf{N}$ & Mean & SD & Q1 & Median & Q3 \\
\hline Deferring Directors & 2,078 & 5.957 & 3.671 & 3.000 & 6.000 & 9.000 \\
\hline \% Outside Directors & 2,078 & 0.598 & 0.318 & 0.300 & 0.625 & 0.900 \\
\hline \multicolumn{7}{|l|}{ Panel B: Amount Deferred } \\
\hline \# Transactions Per Year & 9,935 & 6.215 & 5.610 & 2.000 & 4.000 & 8.000 \\
\hline (\$) Deferred Per Transaction & 9,935 & 36,311 & 68,015 & 6,302 & 15,090 & 36,120 \\
\hline (\$) Total Deferred Per Year & 9,935 & 135,787 & 321,154 & 31,951 & 75,255 & 137,102 \\
\hline \% Cash Deferred Per Year & 9,935 & 0.819 & 0.306 & 0.724 & 1.000 & 1.000 \\
\hline
\end{tabular}




\section{Table 4: Descriptive statistics on director \& firm characteristics}

The table presents descriptive statistics on the selected director- and firm-level determinants of the director equity deferrals. The sample for this table consists of all director-firm-years from the subset of ExecuComp-RiskMetrics firms allowing equity deferral options to directors over the period 1999-2009 with available data on the selected director- and firm-level characteristics (41,295 director-firm-years: 9,935 deferring directors and 31,360 nondeferring directors ). All variables are defined in the text.

\begin{tabular}{|c|c|c|c|c|c|c|}
\hline \multicolumn{7}{|l|}{ Director and Firm Characteristics } \\
\hline & $\mathbf{N}$ & Mean & SD & Q1 & Median & Q3 \\
\hline \multicolumn{7}{|l|}{ Panel A: Contractual features } \\
\hline \multicolumn{7}{|l|}{ Director Compensation: } \\
\hline Cash Deferrable & 41,295 & 54,495 & 32,709 & 32,500 & 48,000 & 71,000 \\
\hline \% Equity Comp & 41,295 & 0.495 & 0.244 & 0.377 & 0.519 & 0.651 \\
\hline Ownership Guidelines & 41,295 & 0.217 & 0.412 & -- & -- & -- \\
\hline \multicolumn{7}{|l|}{ Deferral Options: } \\
\hline Alternative & 41,295 & 0.662 & 0.473 & -- & -- & -- \\
\hline Premium & 41,295 & 0.080 & 0.272 & -- & -- & -- \\
\hline Premium Amount (if Premium =1) & & 0.211 & 0.089 & 0.150 & 0.200 & 0.250 \\
\hline \multicolumn{7}{|l|}{ Panel B: Firm Prospects } \\
\hline \multicolumn{7}{|l|}{ Executive Deferrals: } \\
\hline Exe_Deferrals & 41,295 & 0.093 & 0.290 & -- & -- & -- \\
\hline \multicolumn{7}{|l|}{ Market Performance: } \\
\hline Stock Returns it+1 & 41,295 & 0.092 & 0.386 & -0.149 & 0.075 & 0.285 \\
\hline Stock Returns horizon & 41,295 & 0.094 & 0.344 & -0.104 & 0.071 & 0.251 \\
\hline Stock Returns it-2,t-1 & 41,295 & 0.086 & 0.279 & -0.093 & 0.050 & 0.208 \\
\hline \multicolumn{7}{|l|}{ Panel C: Personal Characteristics } \\
\hline \multicolumn{7}{|l|}{ Profile Inside the Firm: } \\
\hline \% Sharesheld & 41,295 & $0.161 \%$ & $0.644 \%$ & $0.000 \%$ & $0.014 \%$ & $0.057 \%$ \\
\hline Met Guidelines (if Guidelines =1) & & 0.715 & 0.451 & -- & -- & -- \\
\hline Acquisition & 41,295 & 0.091 & 0.288 & -- & -- & -- \\
\hline Tenure & 41,295 & 8.03 & 6.83 & 3 & 6 & 11 \\
\hline Horizon & 41,295 & 1.81 & 0.86 & 1 & 2 & 2 \\
\hline \multicolumn{7}{|l|}{ Profle Outside the Firm: } \\
\hline Other Boards & 41,295 & 1.17 & 1.29 & 0 & 1 & 2 \\
\hline Executive & 41,295 & 0.182 & 0.386 & -- & -- & -- \\
\hline \multicolumn{7}{|l|}{ Other Characteristics: } \\
\hline Age & 41,295 & 61.48 & 7.50 & 57 & 62 & 67 \\
\hline Female & 41,295 & 0.151 & 0.358 & -- & -- & -- \\
\hline \multicolumn{7}{|l|}{ Panel D: Firm-level Controls } \\
\hline $\operatorname{LogMVE~it-1~}_{1}$ & 41,295 & 8.387 & 1.555 & 7.233 & 8.308 & 9.500 \\
\hline$M B_{\text {it-1 }}$ & 41,295 & 3.132 & 3.213 & 1.544 & 2.221 & 3.541 \\
\hline SD(Stock Returns it-2,t-1) & 41,295 & 0.094 & 0.043 & 0.063 & 0.086 & 0.113 \\
\hline
\end{tabular}




\section{Table 5: Univariate comparisons between deferring \& non-deferring directors}

The table presents univariate comparisons between the sub-sample of outside directors electing to defer cash compensation into equity in an year (i.e., deferring directors) and all other directors who received the same option to defer cash into equity in the year but they did not exercise it (i.e., non-deferring directors). The sample for this table consists of all director-firm-years from the subset of ExecuComp-RiskMetrics firms allowing equity deferral options to directors over the period 1999-2009 with available data on the selected director- and firm-level characteristics (41,295 director-firm-years: 9,935 deferring directors and 31,360 non-deferring directors ). ${ }^{* * *}{ }^{* *}, *$ indicate significance levels at $\mathrm{p}<0.01, \mathrm{p}<0.05, \mathrm{p}<0.10$, respectively, from two-tailed t-tests for differences in means between sub-samples. Standard deviations are in parenthesis. All variables are defined in the text.

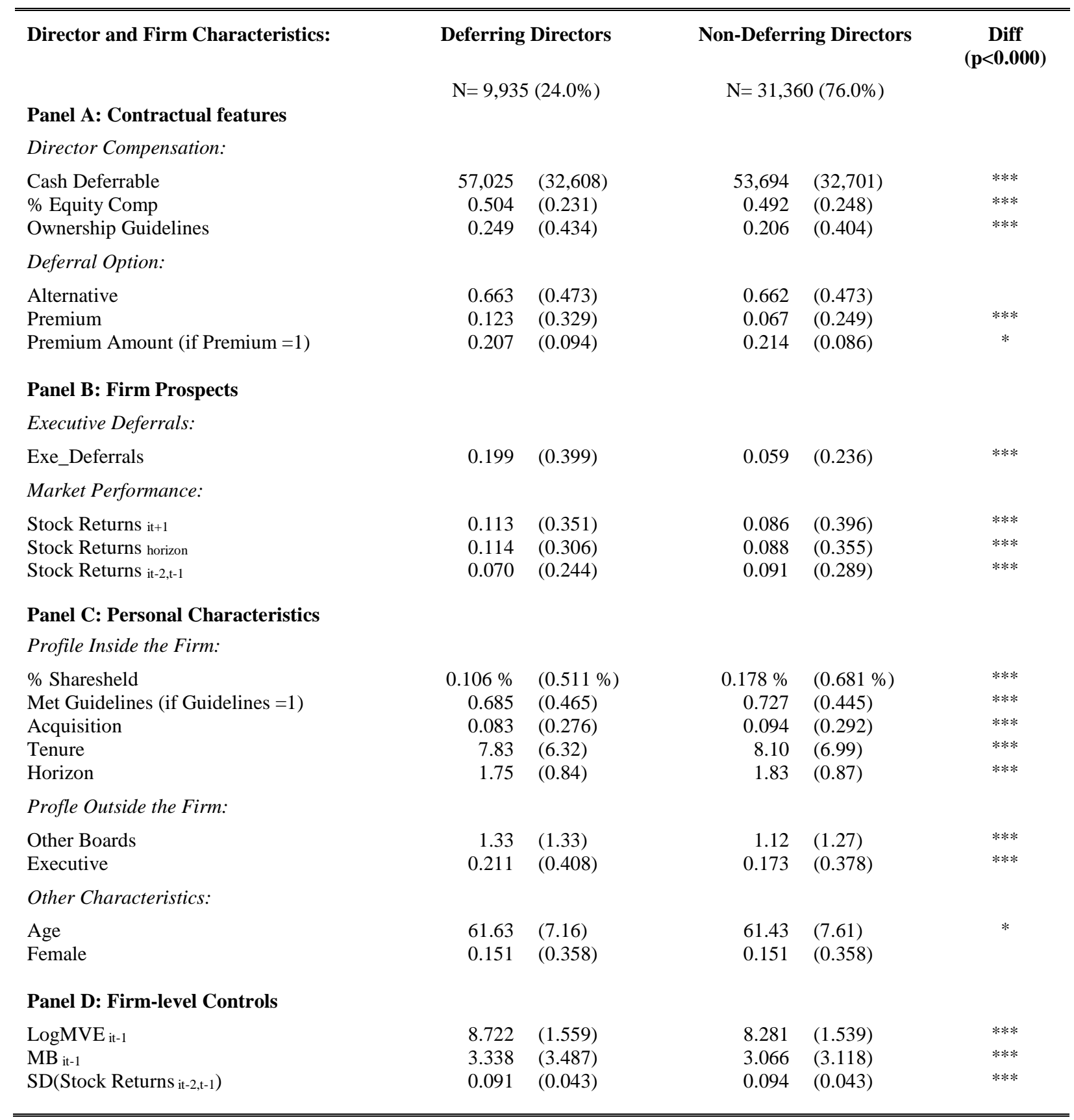




\section{Table 6: Determinants of director equity deferrals: overall sample}

The table presents results from OLS models for the natural logarithm of the total dollar value deferred by the director in the year. The total dollar value that was deferred is computed as the sum of the values from all the deferral transactions the director recorded in the year. The dollar value of the deferral transactions equal the value of the deferred stock units on the day the transactions were filed, as reported in the "trandate" field in Thompson Insider Filings Data. The model in Column I regresses the value of the equity deferrals on our set of determinants plus firm fixed-effects. Column II replicates the model after including the Inverse-Mills ratio from the logit estimates in Table 2 - Panel B for the firm's choice to offer equity deferral options to directors in the year. The sample for this table consists of all director-firm-years from the subset of ExecuComp-RiskMetrics firms allowing equity deferral options to directors over the period 1999-2009 with available data on the selected director- and firmlevel characteristics. We estimate standard errors (in parenthesis) clustered by the directors' identification numbers (the “did" field in RiskMetrics). ${ }^{* * *}{ }^{* *},{ }^{*}$ indicate significance levels at $\mathrm{p}<0.01, \mathrm{p}<0.05, \mathrm{p}<0.10$, respectively. All variables are defined in the text.

\section{Dependent Variable $\rightarrow$}

Constant

\section{Contractual features}

Cash Deferrable

\% Equity Comp

Ownership Guidelines

Alternative

Premium Amount

\section{Firm Prospects}

Exe_Deferrals

Stock Returns horizon

Stock Returns t-2,t-1

\section{Personal Characteristics}

\% Sharesheld

Met Guidelines*Guidelines

Acquisition

Ln(Tenure)

Ln(Horizon)

Ln(Other Boards)

Executive

Ln(Age)

Female

\section{Firm-level Controls}

Ln(MVE) t-1

$\mathrm{MB}_{\mathrm{t}-1}$

$0.011 \quad$ (1.05)

$-0.821 \quad(-1.14)$

MillsRatio

Firm FE

YES

$\mathrm{N}$

Adj. $R^{2}$

\section{Ln(Total Deferred in Year)}

$$
3.086 \quad \text { ( 2.91) }
$$

2.339

0.444

$-0.316$

$-25.707$

$0.061 \quad(0.55)$

$-0.067 \quad(-0.98)$

$0.099 \quad(2.80)$

$0.034 \quad(0.62)$

$0.100 \quad$ (2.03)

$0.192 \quad$ (2.70)

$-0.303 \quad(-1.29)$

$-0.179 \quad(-2.45)$

$\begin{array}{rrr}-0.262 & (-3.89) & * * * \\ 0.032 & (2.87) & * * * \\ 2.009 & (2.61) & * * * \\ -0.899 & (-8.69) & * * *\end{array}$




\section{Table 7: Determinants of director equity deferrals: multiple-board directors}

The table replicates the models in Table 6 over the sub-sample of directors sitting on more than one board in the year (i.e., 3,341 distinct directors in 20,101 director-firm-years). The model in Columns I regresses the value of the equity deferrals on our set of determinants plus firm fixed-effects. Column II replicates the model after including the Inverse-Mills ratio from the logit estimates in Table 2 - Panel B for the firm's choice to offer equity deferral options to directors in the year. We estimate standard errors (in parenthesis) clustered by the directors' identification numbers (the “did" field in RiskMetrics). ${ }^{* * *}{ }^{* *},{ }^{*}$ indicate significance levels at $\mathrm{p}<0.01, \mathrm{p}<0.05, \mathrm{p}<0.10$, respectively. All variables are defined in the text.

Dependent Variable $\rightarrow$

Constant

\section{Contractual features}

Cash Deferrable

\% Equity Comp

Ownership Guidelines

Alternative

Premium Amount

\section{Firm Prospects}

Exe_Deferrals

Stock Returns horizon

Stock Returns t-2,t-1

Personal Characteristics

\% Sharesheld

Met Guidelines*Guidelines

Acquisition

Ln(Tenure)

Ln(Horizon)

Ln(Other Boards)

Executive

Ln(Age)

Female

\section{Firm-level Controls}

Ln(MVE) $\mathrm{t}-1$

$\mathrm{MB}_{\mathrm{t}-1}$

SD(Stock Returns t-2,t-1)

$-0.875$

MillsRatio

Firm FE

$\mathrm{N}$

Adj. $\mathrm{R}^{2}$

I

\section{Ln(Total Deferred in Year)}

$5.174 \quad(3.60)$

$0.000 \quad$ (4.67) ***

$0.614 \quad$ (3.25)

$-0.024 \quad(-0.16)$

$0.390 \quad$ (1.66)

$8.178 \quad$ ( 5.63$)$

$1.577 \quad$ ( 9.64)

$0.508 \quad$ (5.81)

$-0.361 \quad(-3.24)$

$\begin{array}{rrr}-46.460 & (-7.52) & * * * \\ 0.113 & (0.82) & \\ -0.088 & (-0.86) & \\ 0.160 & (3.84) & * * * \\ -0.159 & (-1.52) & \\ 0.110 & (1.44) & \\ 0.262 & (3.67) & * * * \\ -0.323 & (-1.05) & \\ -0.219 & (-2.73) & * * *\end{array}$

$\begin{array}{rll}-0.231 & (-2.86) & * * * \\ 0.029 & (2.27) & * * \\ 2.423 & (2.30) & * * * \\ -1.148 & (-8.73) & * * *\end{array}$

YES

19,008

0.489 


\section{Table 8: Abnormal returns following director equity deferrals}

The table reports summary statistics and significance tests on the abnormal returns following director equity deferral transactions (53,015 transactions). RET $(t+60), \operatorname{RET}(\mathrm{t}+180), \mathrm{RET}(\mathrm{t}+360)$ are the buy-and-hold returns over the $+60,+180,+360$ days following the equity deferral transactions dates (i.e., the "trandate" field in Thompson Insider Filings Data). RET(horizon) cumulates returns between the transaction date and the end of the year in which the director will end her current mandate. RET(final) cumulates returns between the transaction date and the end of the year in which the director will end her last mandate at the firm. Market-adjusted returns are the difference between the firm's stock returns and the market returns, where the S\&P 500 Composite Index is used as a proxy for the market portfolio. Benchmark-adjusted returns are the difference between the firm's stock returns and the returns predicted by the size, book-to-market and momentum model as in Daniel et al. (1997). Panel A compares the abnormal returns of sample directors' equity deferrals to the returns non-deferring directors would have realized if they had exercised their option to defer at their firm on the annual board meeting date. Panel B replicates the analyses within the sub-sample of multiple-board directors electing to defer in some firms but not all of the firms offering equity deferral options between 1999 and 2009. For the sub-sample of firms where multiple-board directors did not register equity deferral transactions in the year we assume that the election would have occurred on the annual board meeting date. ${ }^{* * *}, * *, *$ indicate significance levels at $\mathrm{p}<0.01, \mathrm{p}<0.05, \mathrm{p}<0.10$, respectively, from two-tailed t-tests for differences in means between sub-samples.

Panel A: Overall Sample

\begin{tabular}{|c|c|c|c|c|c|c|c|}
\hline \multirow[b]{2}{*}{ Mkt-Adj Returns } & \multicolumn{3}{|c|}{ Director Deferred = 1} & \multicolumn{3}{|c|}{ Director Deferred = 0} & \multirow{2}{*}{$\begin{array}{c}\text { Diff } \\
(\mathbf{p}<\mathbf{0 . 0 0 0}\end{array}$} \\
\hline & Mean & SD & $\mathrm{p}$-value & Mean & SD & p-value & \\
\hline $\operatorname{RET}(\mathrm{t}+60)$ & 0.025 & $(0.160)$ & 0.000 & 0.016 & $(0.154)$ & 0.000 & $* * *$ \\
\hline $\operatorname{RET}(\mathrm{t}+180)$ & 0.070 & $(0.272)$ & 0.000 & 0.046 & $(0.282)$ & 0.000 & $* * *$ \\
\hline $\operatorname{RET}(\mathrm{t}+360)$ & 0.137 & (0.379) & 0.000 & 0.108 & $(0.415)$ & 0.000 & $* * *$ \\
\hline RET (horizon) & 0.212 & $(0.478)$ & 0.000 & 0.181 & $(0.918)$ & 0.000 & $* * *$ \\
\hline RET (final) & 0.374 & $(0.936)$ & 0.000 & 0.277 & $(1.390)$ & 0.000 & $* * *$ \\
\hline Benchmark-Adj Returns & Mean & SD & $\mathrm{p}$-value & Mean & SD & p-value & \\
\hline $\operatorname{RET}(t+60)$ & 0.005 & $(0.151)$ & 0.000 & -0.001 & $(0.145)$ & 0.331 & $* * *$ \\
\hline $\operatorname{RET}(\mathrm{t}+180)$ & 0.012 & (0.239) & 0.000 & -0.004 & $(0.245)$ & 0.000 & $* * *$ \\
\hline $\operatorname{RET}(\mathrm{t}+360)$ & 0.016 & $(0.309)$ & 0.000 & 0.003 & $(0.352)$ & 0.079 & $* * *$ \\
\hline RET (horizon) & 0.015 & $(0.348)$ & 0.000 & 0.000 & $(0.498)$ & 0.777 & $* * *$ \\
\hline RET (final) & 0.012 & $(0.492)$ & 0.000 & -0.014 & $(0.600)$ & 0.000 & $* * *$ \\
\hline $\mathrm{N}$ & & 53,015 & & & 31,360 & & \\
\hline
\end{tabular}

Panel B: Multiple-Board Directors

\begin{tabular}{|c|c|c|c|c|c|c|c|}
\hline \multirow[b]{2}{*}{ Mkt-Adj Returns } & \multicolumn{3}{|c|}{ Director Deferred = 1} & \multicolumn{3}{|c|}{ Director Deferred $=0$} & \multirow{2}{*}{$\begin{array}{c}\text { Diff } \\
(\mathbf{p}<\mathbf{0 . 0 0 0}\end{array}$} \\
\hline & Mean & SD & p-value & Mean & SD & p-value & \\
\hline $\operatorname{RET}(\mathrm{t}+60)$ & 0.024 & $(0.161)$ & 0.000 & 0.017 & $(0.153)$ & 0.000 & $* * *$ \\
\hline $\operatorname{RET}(\mathrm{t}+180)$ & 0.071 & $(0.276)$ & 0.000 & 0.045 & $(0.279)$ & 0.000 & $* * *$ \\
\hline $\operatorname{RET}(\mathrm{t}+360)$ & 0.138 & $(0.388)$ & 0.000 & 0.110 & $(0.415)$ & 0.000 & $* * *$ \\
\hline RET (horizon) & 0.218 & $(0.502)$ & 0.000 & 0.194 & $(1.055)$ & 0.000 & $* * *$ \\
\hline \multirow[t]{2}{*}{ RET (final) } & 0.382 & (0.933) & 0.000 & 0.309 & (1.777) & 0.000 & $* * *$ \\
\hline & \multicolumn{3}{|c|}{ Director Deferred = 1} & \multicolumn{3}{|c|}{ Director Deferred = 0} & \\
\hline Benchmark-Adj Returns & Mean & SD & p-value & Mean & SD & p-value & \\
\hline $\operatorname{RET}(\mathrm{t}+60)$ & 0.005 & $(0.152)$ & 0.000 & 0.001 & $(0.143)$ & 0.165 & $* * *$ \\
\hline $\operatorname{RET}(\mathrm{t}+180)$ & 0.016 & $(0.243)$ & 0.000 & -0.004 & $(0.243)$ & 0.008 & $* * *$ \\
\hline $\operatorname{RET}(\mathrm{t}+360)$ & 0.024 & $(0.321)$ & 0.000 & 0.009 & $(0.353)$ & 0.000 & $* * *$ \\
\hline RET (horizon) & 0.026 & $(0.363)$ & 0.000 & 0.017 & $(0.541)$ & 0.000 & $* *$ \\
\hline RET (final) & 0.019 & $(0.498)$ & 0.000 & -0.002 & $(0.670)$ & 0.555 & $* * *$ \\
\hline $\mathrm{N}$ & \multicolumn{3}{|c|}{28,536} & \multicolumn{3}{|c|}{14,651} & \\
\hline
\end{tabular}


Table 9: Cross-sectional variation in abnormal returns

The table provides multivariate analyses for the trading performance of director equity deferrals as a function of selected firm, board and director compensation plans characteristics. The sample for this table consists of 49,422 equity deferrals registered by outside directors between 1999 and 2009 with available data on the selected variables. Panel A (Panel B) reports results for cumulated market-adjusted (benchmark-adjusted) returns at the $+60,+180$, +360 days following the equity deferral transactions dates (i.e., the "trandate" field in Thompson Insider Filings Data). RET(horizon) cumulates returns between the equity deferral transaction date and the end of the year in which the director will end her current mandate. Bad Governance is an indicator equal to 1 if the firm's Gompers, Ishii, and Metrick (2003) Governance Index falls into the top quartile of sample distribution. \% Insiders measure the proportion of board members with RiskMetrics “dirtype” field equal to “E” (i.e., “Employee”). Analysts Following measure the number of analysts following the firm in the year as the retrieved from IBES. Management Forecasts is the number of forecasts issued by the firm's executive in the year. Audit, Governance, and Compensation are indicator variables equal to 1if the director serves on the audit, governance, and compensation committee, respectively. Attendance is an indicator variable for whether the director attended more than $75 \%$ of the board meetings. Transaction size is the number of shares traded scaled by the number of shares outstanding at the beginning of the quarter. All models include firm fixed-effects and cluster standard errors (in parenthesis) clustered by the directors' identification numbers (the “did” field in RiskMetrics). ${ }^{* * *},{ }^{* *},{ }^{*}$ indicate significance levels at $\mathrm{p}<$ $0.01, \mathrm{p}<0.05, \mathrm{p}<0.10$, respectively.

\begin{tabular}{|c|c|c|c|c|c|c|c|c|}
\hline \multirow{3}{*}{$\begin{array}{l}\text { Panel A: } \\
\text { Constant }\end{array}$} & \multicolumn{8}{|c|}{ Mkt-Adj Returns } \\
\hline & \multicolumn{2}{|c|}{$\operatorname{RET}(\mathrm{t}+60)$} & \multicolumn{2}{|c|}{$\operatorname{RET}(\mathrm{t}+180)$} & \multicolumn{2}{|c|}{$\operatorname{RET}(\mathrm{t}+360)$} & \multicolumn{2}{|c|}{ RET (horizon) } \\
\hline & 0.161 & $(7.57)^{* * *}$ & 0.370 & $(7.67)^{* * *}$ & 0.521 & $(6.99)^{* * *}$ & 0.879 & $(7.17)^{* * *}$ \\
\hline $\begin{array}{l}\text { Bad Governance } \\
\text { \% Insiders } \\
\text { Board Size } \\
\text { Analysts Following } \\
\text { Management Forecasts } \\
\text { Audit } \\
\text { Governance } \\
\text { Compensation } \\
\text { Attendance }\end{array}$ & $\begin{array}{r}0.008 \\
0.079 \\
-0.008 \\
-0.003 \\
-0.002 \\
0.001 \\
-0.001 \\
0.002 \\
-0.012\end{array}$ & $\begin{array}{l}(1.89)^{*} \\
(3.42)^{* * *} \\
(-9.11)^{* * *} \\
(-7.36)^{* * *} \\
(-3.00)^{* * *} \\
(0.55) \\
(-0.46) \\
(0.87) \\
(-0.92)\end{array}$ & $\begin{array}{r}0.027 \\
0.186 \\
-0.013 \\
-0.008 \\
-0.009 \\
0.001 \\
-0.005 \\
-0.000 \\
-0.023\end{array}$ & $\begin{array}{l}(3.23)^{* * * *} \\
(2.87)^{* * * *} \\
(-6.88)^{* * *} \\
(8.96)^{* * *} \\
(-5.77)^{* * *} \\
(0.18) \\
(-1.30) \\
(-0.08) \\
(-0.83)\end{array}$ & $\begin{array}{r}0.042 \\
0.687 \\
-0.015 \\
-0.014 \\
-0.015 \\
0.005 \\
-0.006 \\
0.001 \\
-0.034\end{array}$ & $\begin{array}{l}(3.17)^{* * *} \\
(6.40)^{* * *} \\
(-4.82)^{* * *} \\
(-8.58)^{* * *} \\
(-6.54)^{* * *} \\
(0.77) \\
(-0.81) \\
(0.15) \\
(-0.77)\end{array}$ & $\begin{array}{r}0.066 \\
0.999 \\
-0.019 \\
-0.016 \\
-0.025 \\
0.004 \\
-0.018 \\
0.004 \\
-0.080\end{array}$ & $\begin{array}{l}(3.56)^{* * *} \\
(6.27)^{* * *} \\
(-3.92)^{* * *} \\
(7.86)^{* * *} \\
(-7.62)^{* * *} \\
(0.45) \\
(-1.66)^{*} \\
(0.39) \\
(-1.57)\end{array}$ \\
\hline $\begin{array}{l}\text { Ownership Guidelines } \\
\text { Premium Amount } \\
\text { \% Income Tax Rate }\end{array}$ & $\begin{array}{l}-0.006 \\
-0.066 \\
-0.140\end{array}$ & $\begin{array}{l}(-1.67)^{*} \\
(-0.83) \\
(-0.66)\end{array}$ & $\begin{array}{l}-0.009 \\
-0.639 \\
-0.278\end{array}$ & $\begin{array}{l}(-1.14) \\
(-4.21)^{* * *} \\
(-0.52)\end{array}$ & $\begin{array}{l}-0.039 \\
-0.840 \\
-0.887\end{array}$ & $\begin{array}{l}(-2.78)^{* * *} \\
(-3.24)^{* * *} \\
(-1.06)\end{array}$ & $\begin{array}{l}-0.055 \\
-1.473 \\
-3.771\end{array}$ & $\begin{array}{l}(-2.96)^{* * *} \\
(-7.62)^{* * *} \\
(-2.84)^{* * *}\end{array}$ \\
\hline Transaction Size & 0.006 & $(2.38)^{* *}$ & 0.018 & $(2.76)^{* * *}$ & 0.021 & $(2.88)^{* * *}$ & 0.024 & $(3.25)^{* * *}$ \\
\hline Firm FE & \multicolumn{2}{|c|}{ YES } & \multicolumn{2}{|c|}{ YES } & \multicolumn{2}{|c|}{ YES } & \multicolumn{2}{|r|}{ YES } \\
\hline $\begin{array}{l}\mathrm{N} \\
\text { Adj. } \mathrm{R}^{2}\end{array}$ & \multicolumn{2}{|c|}{49,422} & \multicolumn{2}{|c|}{0.140} & \multicolumn{2}{|c|}{0.236} & \multicolumn{2}{|r|}{0.330} \\
\hline \multirow[t]{2}{*}{ Panel B: } & \multicolumn{8}{|c|}{ Benchmark-Adj Returns } \\
\hline & \multicolumn{2}{|c|}{$\operatorname{RET}(\mathrm{t}+60)$} & \multicolumn{2}{|c|}{$\operatorname{RET}(\mathrm{t}+180)$} & \multicolumn{2}{|c|}{$\operatorname{RET}(\mathrm{t}+360)$} & \multicolumn{2}{|c|}{ RET (horizon) } \\
\hline Constant & 0.107 & $(5.17) * * *$ & 0.175 & $(4.01)^{* * *}$ & 0.159 & $(2.31)^{* *}$ & 0.367 & $(4.15)^{* * *}$ \\
\hline $\begin{array}{l}\text { Bad Governance } \\
\text { \% Insiders } \\
\text { Board Size } \\
\text { Analysts Following } \\
\text { Management Forecasts } \\
\text { Audit } \\
\text { Governance } \\
\text { Compensation } \\
\text { Attendance }\end{array}$ & $\begin{array}{r}0.007 \\
0.018 \\
-0.005 \\
-0.003 \\
0.001 \\
-0.000 \\
-0.000 \\
0.001 \\
-0.009\end{array}$ & $\begin{array}{l}(2.08)^{* *} \\
(0.84) \\
(-6.37)^{* * *} \\
(-6.60)^{* * *} \\
(1.75)^{*} \\
(-0.02) \\
(-0.03) \\
(0.70) \\
(-0.73)\end{array}$ & $\begin{array}{r}0.037 \\
0.108 \\
-0.008 \\
-0.006 \\
-0.003 \\
-0.001 \\
-0.001 \\
0.000 \\
-0.015\end{array}$ & $\begin{array}{l}(5.07) * * * \\
(1.98)^{* *} \\
(-4.82)^{* * *} \\
(-6.95)^{* * *} \\
(-2.24)^{* *} \\
(-0.35) \\
(-0.54) \\
(0.14) \\
(-0.57)\end{array}$ & $\begin{array}{r}0.063 \\
0.533 \\
-0.009 \\
-0.009 \\
-0.007 \\
0.005 \\
0.004 \\
0.005 \\
-0.025\end{array}$ & $\begin{array}{l}(5.60)^{* * *} \\
(5.98)^{* * *} \\
(-3.80)^{* * *} \\
(-5.72)^{* * *} \\
(-3.26)^{* * *} \\
(0.92) \\
(0.70) \\
(0.79) \\
(-0.63)\end{array}$ & $\begin{array}{r}0.083 \\
0.578 \\
-0.019 \\
-0.010 \\
-0.012 \\
0.010 \\
0.008 \\
0.014 \\
-0.077\end{array}$ & $\begin{array}{l}(5.70)^{* * *} \\
(5.07)^{* * *} \\
(-5.00)^{* * *} \\
(-5.56)^{* * *} \\
(-4.85)^{* * *} \\
(1.45) \\
(1.11) \\
(1.93)^{*} \\
(-1.95)^{*}\end{array}$ \\
\hline $\begin{array}{l}\text { Ownership Guidelines } \\
\text { Premium Amount } \\
\text { \% Income Tax Rate }\end{array}$ & $\begin{array}{l}-0.009 \\
-0.149 \\
-0.115\end{array}$ & $\begin{array}{l}(-3.21)^{* * *} \\
(-1.84)^{*} \\
(-0.55)\end{array}$ & $\begin{array}{r}-0.017 \\
-0.417 \\
0.259\end{array}$ & $\begin{array}{l}(-2.49)^{* *} \\
(-3.92)^{* * *} \\
(0.54)\end{array}$ & $\begin{array}{r}-0.042 \\
-0.777 \\
0.882\end{array}$ & $\begin{array}{l}(-3.69)^{* * *} \\
(-5.05)^{* * *} \\
(1.13)\end{array}$ & $\begin{array}{r}-0.065 \\
-1.027 \\
0.235\end{array}$ & $\begin{array}{l}(-4.20)^{* * *} \\
(-7.99)^{* * *} \\
(0.25)\end{array}$ \\
\hline Transaction Size & 0.004 & $(2.22)^{* *}$ & 0.011 & $(2.55)^{* *}$ & 0.014 & $(2.71)^{* * *}$ & 0.011 & $(2.37)^{* * *}$ \\
\hline Firm FE & & YES & & YES & & YES & & YES \\
\hline $\begin{array}{l}\mathrm{N} \\
\text { Adj. } \mathrm{R}^{2}\end{array}$ & & $\begin{array}{l}9,422 \\
.111\end{array}$ & & $\begin{array}{l}9,422 \\
.133\end{array}$ & & $\begin{array}{l}9,422 \\
.226\end{array}$ & & $\begin{array}{c}49,422 \\
0.288\end{array}$ \\
\hline
\end{tabular}




\section{Table 10: Director equity deferrals around earnings announcements}

The table provides average transaction size and values of sample directors' equity and open market stock purchases around earnings announcement days (day 0). The sample for Panel A consists of 53,015 equity deferrals and 10,081 open market purchases registered by the outside directors in firms allowing director equity deferrals between 1999 and 2009. The sample for Panel B consists of 53,015 equity deferrals and 3,130 open market purchases registered by the outside directors in firms registering at least one director equity deferral transaction between 1999 and 2009. Transaction size is the number of shares traded scaled by number of shares outstanding at the beginning of the quarter. We multiply transaction size with 1,000 for ease of exposition. Transaction value (\$) measures the dollar value of the shares on the day the transactions were filed, as reported in the "trandate" field in Thompson Insider Filings Data. Observations are split into 2 groups based on whether they occur in blackout periods or not. Blackout period is -47 to +2 days trading days relative to earnings announcement day and non-blackout period is +3 to +12 trading days relative to earnings announcement day. To calculate the statistics in this table, we first sum total equity deferrals and open market purchases for each firm-day and then compute transaction size means across firm-days.

Panel A: All firms allowing director equity deferrals

\begin{tabular}{|c|c|c|c|c|c|}
\hline \multirow[t]{2}{*}{ Transaction Size: } & \multicolumn{2}{|c|}{ Equity Deferrals } & \multicolumn{2}{|c|}{ Open Market Purchases } & \multirow[t]{2}{*}{ Diff $(p<0.000)$} \\
\hline & $\mathrm{N}$ & Mean & $\mathrm{N}$ & Mean & \\
\hline Non-Blackout Days & 7,020 & 0.0055 & 7,020 & 0.0139 & $-0.0082(* * *)$ \\
\hline Blackout Days & 35,100 & 0.0043 & 35,100 & 0.0037 & $0.0006(* * *)$ \\
\hline Diff $(p<0.000)$ & \multicolumn{2}{|c|}{$0.0012(* * *)$} & \multicolumn{2}{|c|}{$0.0101(* * *)$} & \\
\hline \multirow[t]{2}{*}{ Transaction Values (\$): } & \multicolumn{2}{|c|}{ Equity Deferrals } & \multicolumn{2}{|c|}{ Open Market Purchases } & Diff $(p<0.000)$ \\
\hline & $\mathrm{N}$ & Mean & $\mathrm{N}$ & Mean & \\
\hline Non-Blackout Days & 7,020 & 20,302 & 7,020 & 30,101 & $-9,187(* * *)$ \\
\hline Blackout Days & 35,100 & 15,691 & 35,100 & 8,203 & $7,471(* * *)$ \\
\hline Diff $(p<0.000)$ & \multicolumn{2}{|c|}{$4,612(* * *)$} & \multicolumn{2}{|c|}{$21,899(* * *)$} & \\
\hline
\end{tabular}

Panel B: Firms with at least one deferring director

\begin{tabular}{|c|c|c|c|c|c|}
\hline \multirow[t]{2}{*}{ Transaction Size: } & \multicolumn{2}{|c|}{ Equity Deferrals } & \multicolumn{2}{|c|}{ Open Market Purchases } & \multirow[t]{2}{*}{ Diff $(p<0.000)$} \\
\hline & $\mathrm{N}$ & Mean & $\mathrm{N}$ & Mean & \\
\hline Non-Blackout Days & 4,140 & 0.0112 & 4,140 & 0.0046 & $0.0065(* * *)$ \\
\hline Blackout Days & 20,700 & 0.0085 & 20,700 & 0.0012 & $0.0074(* * *)$ \\
\hline Diff $(p<0.000)$ & \multicolumn{2}{|c|}{$0.0027(* * *)$} & \multicolumn{2}{|c|}{$0.0035(* * *)$} & \\
\hline \multirow[t]{2}{*}{ Transaction Values (\$): } & \multicolumn{2}{|c|}{ Equity Deferrals } & \multicolumn{2}{|c|}{ Open Market Purchases } & Diff $(p<0.000)$ \\
\hline & $\mathrm{N}$ & Mean & $\mathrm{N}$ & Mean & \\
\hline Non-Blackout Days & 4,140 & 42,769 & 4,140 & 17,659 & $25,594(* * *)$ \\
\hline Blackout Days & 20,700 & 31,360 & 20,700 & 4,606 & $26,729(* * *)$ \\
\hline Diff $(p<0.000)$ & \multicolumn{2}{|c|}{$11,409(* * *)$} & \multicolumn{2}{|c|}{$13,053(* * *)$} & \\
\hline
\end{tabular}




\section{Figure 1: Number of transactions by time of the year}

The figure plots the average number of director equity deferral transactions by day of the year. The sample for this figure consists of 53,015 transactions filed by 9,935 outside directors in 2,078 firms with available data on ExecuComp and RiskMetrics between 1999 and 2009.

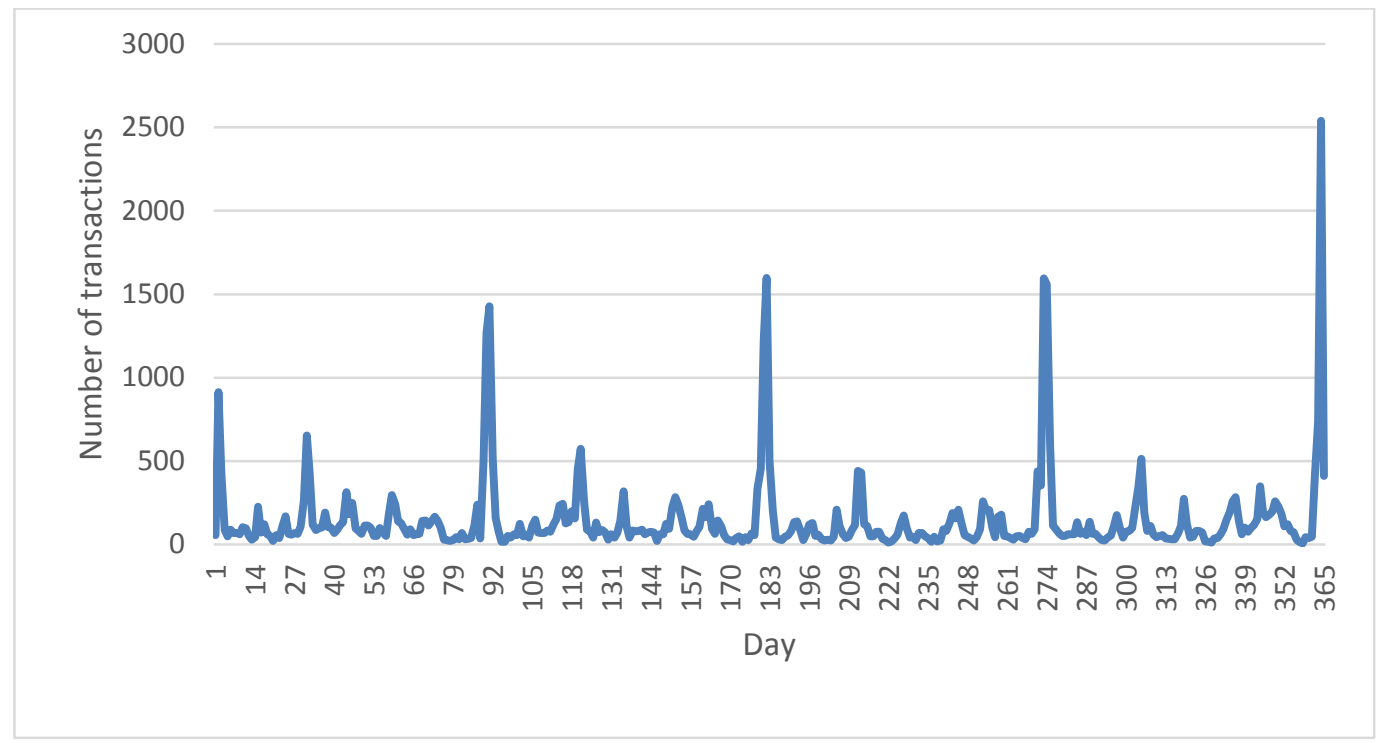




\section{Figure 2: Abnormal returns around director equity deferrals}

The figure plots cumulative abnormal stock returns following sample directors' equity deferral transaction dates (day 0). The sample for this figure consists of 53,015 transactions filed by 9,935 outside directors in 2,078 firms with available data on ExecuComp and RiskMetrics between 1999 and 2009. The figure shows the cumulative abnormal returns from 30 days before through 360 days after the equity deferrals' transaction dates. Marketadjusted returns are the difference between the firm's stock returns and the market returns, where the S\&P 500 Composite Index is used as a proxy for the market portfolio. Benchmark-adjusted returns are the difference between the firm's stock returns and the Daniel, Grinblatt, Titman, and Wermers (1997) benchmark returns. For ease of exposition, we multiply abnormal returns measures by 100.

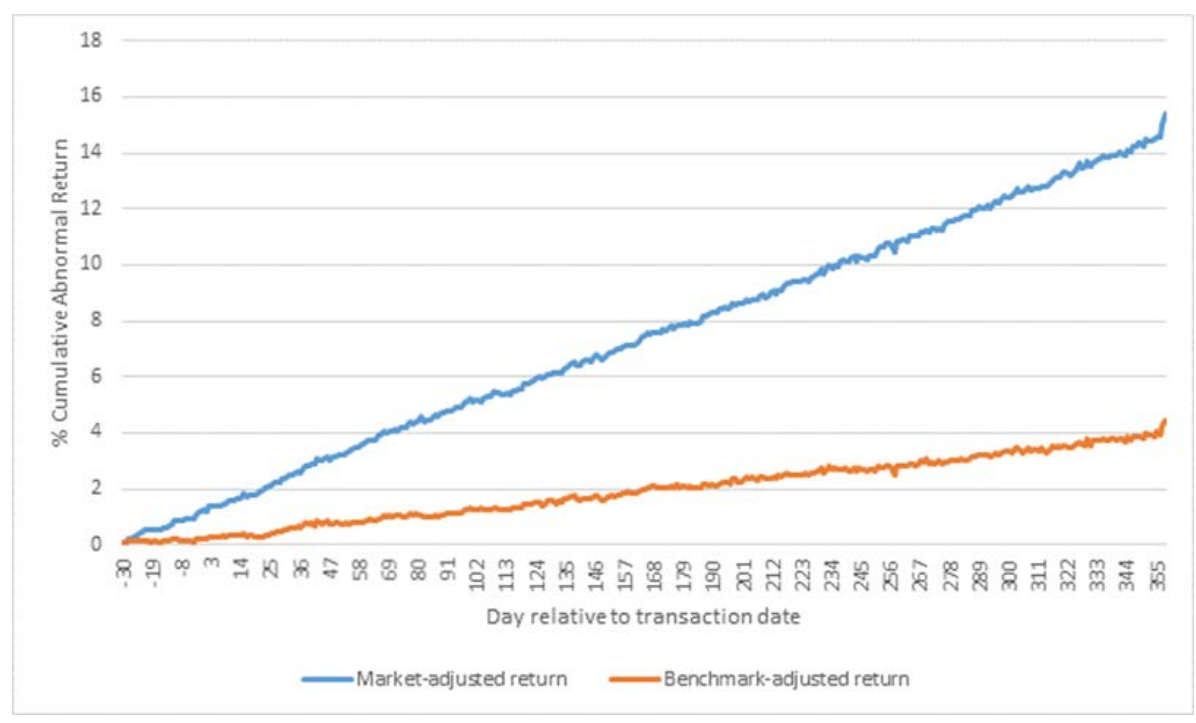




\section{Figure 3: Director equity deferrals around earnings announcement dates}

The figure plots the average transaction size of directors' equity deferrals and open market purchases around earnings announcement dates. The sample for figure A consists of 53,015 equity deferrals and 10,081 open market purchases registered by the outside directors in firms allowing director equity deferrals between 1999 and 2009 . The sample for figure B consists of 53,015 equity deferrals and 3,130 open market purchases registered by the outside directors in firms registering at least one director equity deferral transaction between 1999 and 2009. Transaction size is number of shares traded scaled by number of shares outstanding at the beginning of the quarter. We multiply transaction size with 1,000 for ease of exposition. In order to construct this plot, we first sum total equity deferrals and open market purchases for each firm-day and then compute transaction size means across firmdays.

Figure 3.A: All firms allowing director equity deferrals

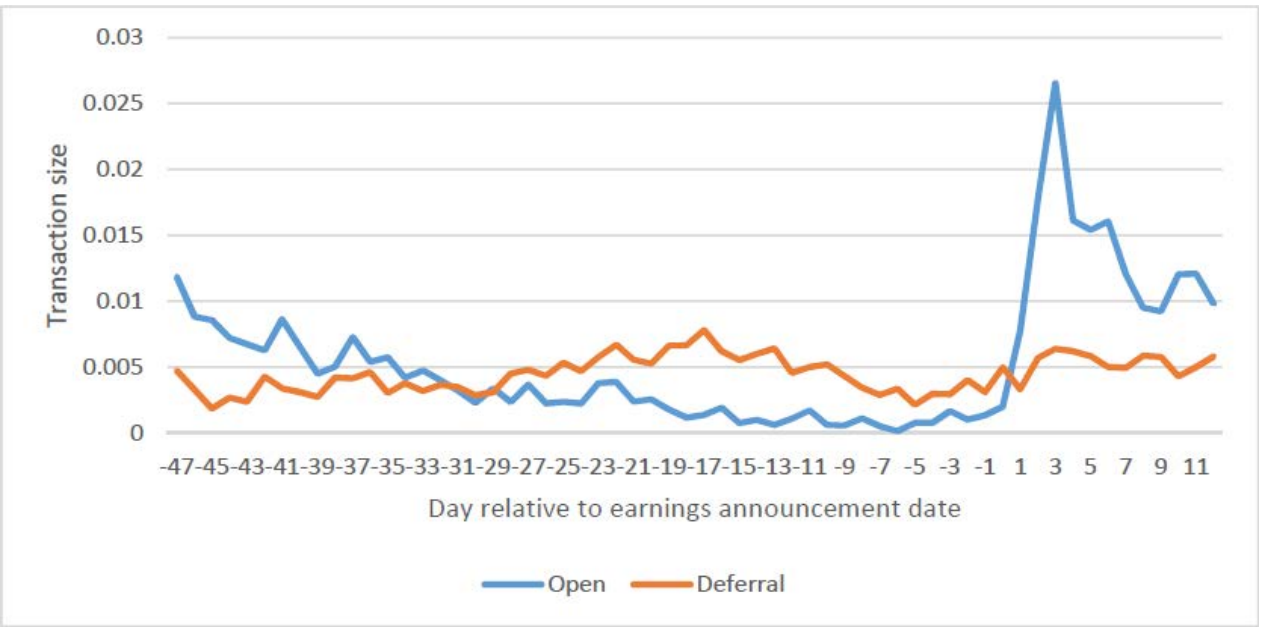

Figure 3.B: Firms with at least one deferring director

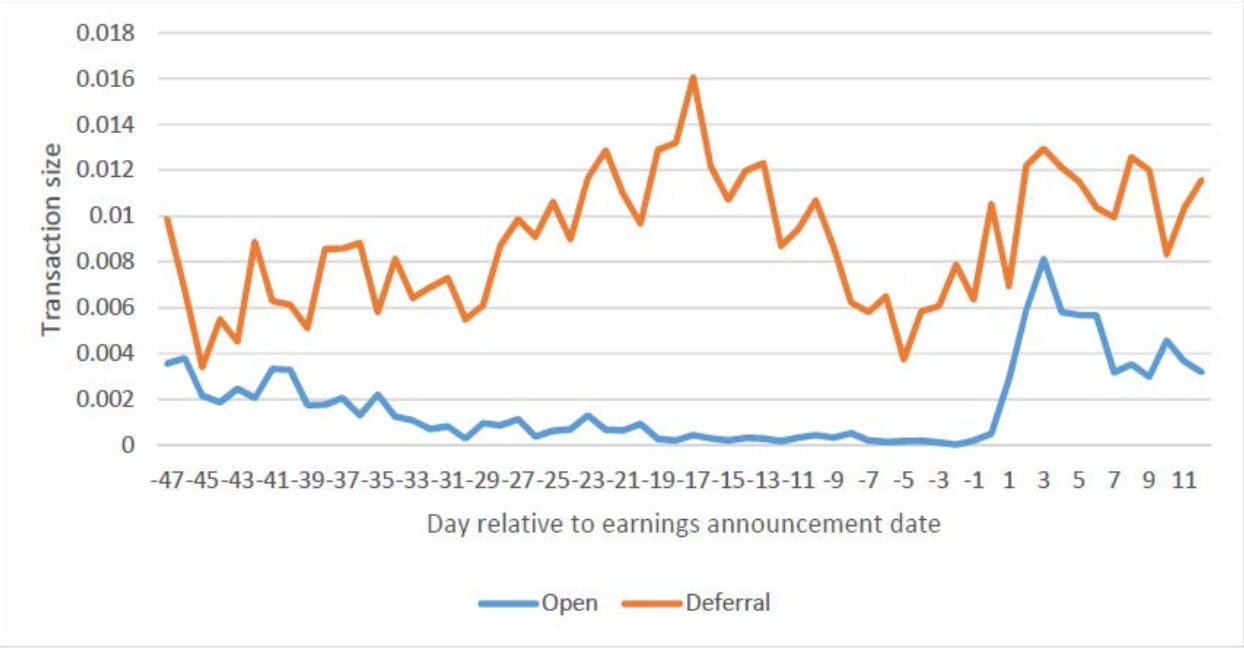

